\title{
Impacts of HONO sources on the photochemistry in Mexico City during the MCMA-2006/MILAGO Campaign
}

\author{
G. Li ${ }^{1,2}$, W. Lei ${ }^{1}$, M. Zavala ${ }^{1}$, R. Volkamer ${ }^{3,4}$, S. Dusanter ${ }^{5}$, P. Stevens ${ }^{5}$, and L. T. Molina ${ }^{1,2}$ \\ ${ }^{1}$ Molina Center for the Energy and the Environment, La Jolla, CA 92037, USA \\ ${ }^{2}$ Massachusetts Institute of Technology, Cambridge, MA 02139, USA \\ ${ }^{3}$ Department of Chemistry, University of Colorado at Boulder, Boulder, CO 80309, USA \\ ${ }^{4}$ Cooperative Institute for Research in the Environmental Sciences (CIRES), University of Colorado at Boulder, Boulder, \\ CO 80309, USA \\ ${ }^{5}$ Center for Research in Environmental Science, School of Public and Environmental Affairs, and Department of Chemistry, \\ Indiana University, Bloomington, IN 47405, USA
}

Received: 14 January 2010 - Published in Atmos. Chem. Phys. Discuss.: 11 February 2010

Revised: 9 June 2010 - Accepted: 6 July 2010 - Published: 16 July 2010

\begin{abstract}
The contribution of HONO sources to the photochemistry in Mexico City is investigated during the MCMA2006/MILAGO Campaign using the WRF-CHEM model. Besides the homogeneous reaction of $\mathrm{NO}$ with $\mathrm{OH}$, four additional HONO sources are considered in the WRF-CHEM model: secondary $\mathrm{HONO}$ formation from $\mathrm{NO}_{2}$ heterogeneous reaction with semivolatile organics, $\mathrm{NO}_{2}$ reaction with freshly emitted soot, $\mathrm{NO}_{2}$ heterogeneous reaction on aerosol and ground surfaces. The WRF-CHEM model with the five HONO sources performs reasonably well in tracking the observed diurnal variation of HONO concentrations. The HONO sources included are found to significantly improve the $\mathrm{HO}_{\mathrm{x}}\left(\mathrm{OH}+\mathrm{HO}_{2}\right)$ simulations during daytime and the partition of $\mathrm{NO} / \mathrm{NO}_{2}$ in the morning. The $\mathrm{HONO}$ sources also accelerate the accumulation of $\mathrm{O}_{3}$ concentrations in the morning by about $2 \mathrm{~h}$ and subsequently result in a noticeable enhancement of $\mathrm{O}_{3}$ concentrations over the course of the day with a midday average of about $6 \mathrm{ppb}$. Furthermore, these HONO sources play a very important role in the formation of secondary aerosols in the morning. They substantially enhance the secondary organic aerosol concentrations by a factor of 2 on average in the morning, although they contribute less during the rest of the day. The simulated particle-phase nitrate and ammonium are also substantially enhanced in the morning when the four HONO sources are included, in good agreement with the measurements. The impact of the HONO sources on the sulfate aerosols is negligible because of the inefficient conversion of $\mathrm{H}_{2} \mathrm{SO}_{4}$ from $\mathrm{SO}_{2}$ reacting with $\mathrm{OH}$.
\end{abstract}

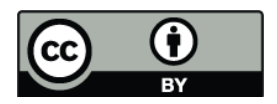

Correspondence to: $\mathrm{G}$. $\mathrm{Li}$ (lgh@mce2.org)

\section{Introduction}

Nitrous acid (HONO) plays an important role in the photochemistry of the troposphere, especially in the polluted urban atmosphere, because HONO is a significant photochemical precursor of the hydroxyl radical $(\mathrm{OH})$, the key oxidant in the degradation of most air pollutants (e.g., Jenkin et al., 1988; Calvert et al., 1994; Aumont et al., 2003; Stemmler et al., 2006; Volkamer et al., 2007). Photolysis of HONO by sunlight in the wavelength range from 300 to $405 \mathrm{~nm}$ leads to the production of NO and OH (e.g., Stutz et al., 2000):

$\mathrm{HONO}+h v \rightarrow \mathrm{NO}+\mathrm{OH} \quad(300 \mathrm{~nm}<\lambda<405 \mathrm{~nm})$

Therefore, the formation and photolysis of HONO could enhance the production of ozone $\left(\mathrm{O}_{3}\right)$ and other secondary pollutants, particularly in the early morning when other $\mathrm{OH}$ sources are less important in the polluted atmosphere (Lammel and Perner, 1988; Harrison et al., 1996; Kurtenbach et al., 2001).

A wide range of HONO concentrations in the atmosphere have been reported, with maximum at night and minimum during daytime (Kleffmann et al., 2006). For example, a maximum of $15 \mathrm{ppb}$ was observed in Los Angeles (Winer and Biermann, 1994) and $10 \mathrm{ppb}$ was measured in Milan, Italy (Febo et al., 1996). High values of HONO (100$400 \mathrm{ppt}$ ) are also detected during the day in urban areas (e.g., Febo et al., 1996) and rural regions (53-110 ppt) (e.g., Staffelbach et al., 1997; Zhou et al., 2002; Acker et al., 2005).

The main gas phase source of HONO is the reaction of NO with $\mathrm{OH}$, which frequently fails to explain the observed high

Published by Copernicus Publications on behalf of the European Geosciences Union. 
daytime and nighttime HONO concentrations (Aumont et al., 1999; Stafelbach et al., 1997). Recently, gas-phase production of HONO has been observed during the photolysis of different ortho-nitrophenols (Bejan et al., 2006; Kleffmann, 2007), with a noontime HONO production of $100 \mathrm{pptv} \mathrm{h}^{-1}$ in the urban regions. In addition, the gas-phase photolysis of methyl-substituted nitroaromatics is also proposed to produce HONO (Kleffmann, 2007). Although HONO formation mechanism in the atmosphere is still poorly understood at present, it is well established that heterogeneous conversion processes of nitrogen dioxide $\left(\mathrm{NO}_{2}\right)$ on different surfaces are involved in the troposphere (Febo et al., 1987; Svensson et al., 1987; Saliba et al., 2000; Kleffmann et al., 1998; Lammel and Cape, 1996). In the stratosphere, when the temperature is below $230 \mathrm{~K}$, heterogeneous reactions of $\mathrm{HONO}$ on sulfate aerosols have been observed with an uptake coefficient ranging from 0.03 to 0.1 , dependent on the sulfuric acid content (Zhang et al., 1996). However, considering the high temperature in the troposphere, the heterogeneous loss of HONO on sulfate aerosols cannot constitute a potentially important HONO sink. Direct emissions from vehicles may also play a role in atmospheric HONO levels, depending on vehicle engines and traffic distributions, with a molar emission ratio of $\mathrm{HONO} / \mathrm{NO}_{\mathrm{x}}$ ranging from $10^{-4}$ to $10^{-2}$ (Kurtenbach et al., 2001).

Based on the surface measurements of various radical precursors, Winer and Biermann (1994) investigated the relative contribution of $\mathrm{HONO}$ to $\mathrm{OH}$ sources, showing that $\mathrm{HONO}$ was a major source of $\mathrm{OH}$ during the morning in the polluted Los Angeles atmosphere. Using observations with Differential Optical Absorption Spectroscopy (DOAS), Alicke et al. $(2002,2003)$ found that photolysis of HONO produced up to $34 \%$ of the total $\mathrm{OH}$ formed over 24-h period during BERLIOZ in Germany. Volkamer et al. (2007) also showed that photo-induced HONO sources made an important contribution to the $\mathrm{OH}$ level in the early morning during the MCMA-2003 field campaign in Mexico City.

Modeling results reported in the literature indicate that the contribution of HONO to the atmospheric photochemistry depends on multiple conditions, such as $\mathrm{NO}_{\mathrm{x}}$ concentration, season, etc. In the pioneering modeling study by Harris et al. (1982) using a trajectory model, various levels of HONO were included in the early morning at the beginning of the simulations. The initial HONO input was found to remarkably enhance the production rate of $\mathrm{O}_{3}$ but not significantly influence the maximum $\mathrm{O}_{3}$ yield, except under high $\mathrm{NO}_{\mathrm{x}}$ conditions. Using a box model, Jenkin et al. (1988) found that the photolysis of HONO in the early morning led to a $50 \%$ increase of $\mathrm{OH}$ at $0600 \mathrm{GMT}$, a $14 \%$ increase in the daily maximum $\mathrm{OH}$ and a $16 \%$ increase in net photochemical $\mathrm{O}_{3}$ production when a heterogeneous HONO source was added. Similar results were also obtained by Kotamarthi et al. (2001) using a box model, showing that HONO formation on aerosols substantially influenced $\mathrm{O}_{3}, \mathrm{OH}$, and $\mathrm{HO}_{2}$ concentrations in the polluted planetary boundary layer (PBL).
Furthermore, employing a photochemical trajectory model, Clapp and Jenkin (2001) suggested that direct emission of HONO may have an important impact on the level of oxidant $\left(\mathrm{O}_{3}+\mathrm{NO}_{2}\right)$, especially under more polluted conditions. Based on the simulations with a chemical transport model, Lei et al. (2004) concluded that heterogeneous conversion of $\mathrm{NO}_{2}$ to $\mathrm{HONO}$ on the surfaces of soot aerosol accelerated the $\mathrm{O}_{3}$ production by about $1 \mathrm{~h}$ in the morning and led to a noticeable increase of $7 \mathrm{ppb}$ on average in the daytime $\mathrm{O}_{3}$ level. However, in the simulations performed by Aumont et al. (1999) using a two-layer box model, the photolysis of HONO did not contribute significantly to summertime $\mathrm{O}_{3}$ concentrations of polluted air masses. Furthermore, Aumont et al. (2003) conducted simulations with a two-layer box model to verify the impact of HONO photolysis on the $\mathrm{NO}_{\mathrm{x}} / \mathrm{HO}_{\mathrm{x}} / \mathrm{O}_{3}$ chemistry in the polluted boundary layer. Three HONO sources were added in their simulations, including direct emissions of $\mathrm{HONO}, \mathrm{NO}_{2}$ heterogeneous production of HONO on the ground surface and the aerosol surface. Their simulation results varied with the season: $\mathrm{HONO}$ sources were found to slightly influence the $\mathrm{NO}_{\mathrm{x}} / \mathrm{HO}_{\mathrm{x}} / \mathrm{O}_{3}$ concentration profiles during summer, but the photolysis of $\mathrm{HONO}$ appeared to be a significant source of $\mathrm{OH}$ during winter.

As an important contributor of $\mathrm{OH}$ in the polluted atmosphere, HONO sources potentially affect the formation of secondary aerosols by enhancing the VOC oxidation due to the increased $\mathrm{OH}$ level. However, few studies have been conducted to investigate the impacts of HONO sources on the formation of secondary aerosols in the polluted atmosphere.

During the MCMA-2006 field campaign as part of the MILAGRO (Megacity Initiative: Local and Global Research Observations) project in March 2006, an extensive data set was obtained, including highly time-resolved ambient gas phase species and aerosols (Molina et al., 2008; 2010), which provides a unique opportunity to investigate the impacts of HONO sources on the photochemistry in a polluted urban area. The objective of the present study is to examine the relative importance of different $\mathrm{HONO}$ sources and evaluate their contributions to the $\mathrm{HO}_{\mathrm{x}} / \mathrm{NO}_{\mathrm{x}} / \mathrm{O}_{3}$ chemistry and secondary aerosols using the WRF-CHEM model based on the measurements taken during MCMA-2006 field campaign. The WRF-CHEM model and the model configuration are described in Sect. 2. Results of the modeling experiments and comparisons are presented in Sect. 3. The discussion and summary are given in Sect. 4.

\section{Model description}

\subsection{WRF-CHEM Model}

The WRF Model (Skamarock et al., 2005) is a nextgeneration mesoscale numerical weather prediction (NWP) system designed to serve both operational forecasting and 
atmospheric research needs. A detailed description of the WRF model can be found in the WRF web-site http://www. wrf-model.org/index.php.

Additionally, a chemical model is also fully implemented into the WRF model (WRF-CHEM) (Grell et al., 2005; Tie et al., 2007). Based on the framework of the current WRF-CHEM model and the available emissions inventory in Mexico City (Song et al., 2010), a new flexible gas phase chemical module has been developed and implemented into the WRF-CHEM model, which can be utilized with different chemical mechanisms, including CBIV, RADM2, and SAPRC. The chemistry is solved by an Eulerian backward Gauss-Seidel iterative technique with a number of iterations, inherited from NCAR-HANK (Hess et al., 1999). The short-lived species, such as $\mathrm{OH}$ and $\mathrm{O}\left({ }^{1} \mathrm{D}\right)$, are assumed to be in steady state. The solution is iterated until all species are within $0.1 \%$ of their previous iterative values. For the aerosol simulations, the CMAQ/models 3 (version 4.6) aerosol module developed by US EPA (Environmental Protection Agency), which is designed to be an efficient and economical depiction of aerosol dynamics in the atmosphere, has also been incorporated into the WRFCHEM model (Binkowski and Roselle, 2003). In this aerosol component, the particle size distribution is represented as the superposition of three lognormal sub-distributions called modes. The processes of coagulation, particle growth by the addition of mass, and new particle formation are included. In addition, the wet deposition also follows the method used in the CMAQ/Models3. Surface deposition of chemical species is parameterized following Wesely (1989). The photolysis rates are calculated using the FTUV (Tie et al., 2003; Li et al., 2005). Anthropogenic emissions used in the WRF-CHEM model are constructed from the official emissions inventory for the MCMA-2006 (Song et al., 2010). Biogenic emissions are estimated using the MEGAN v2.04 model (Model of Emissions of Gases and Aerosols from Nature) developed by Guenther et al. (2006, 2007); the on-line biogenic emissions calculation is turned off. In the present study, the SAPRC 99 gas phase chemical mechanism is employed according to the available emission inventory in Mexico City.

\subsection{Parameterization of HONO Sources}

In addition to the homogeneous reaction of $\mathrm{NO}$ with $\mathrm{OH}$, four sources of HONO are included: secondary HONO formation from $\mathrm{NO}_{2}$ heterogeneous reaction with semivolatile organics, $\mathrm{NO}_{2}$ reaction with freshly emitted soot, $\mathrm{NO}_{2}$ heterogeneous reaction on aerosols and ground surface.

With regard to the secondary $\mathrm{HONO}$ formation from $\mathrm{NO}_{2}$ heterogeneous reaction with semivolatile organics, we follow the results of a recent experimental study performed by Gutzwiller et al. (2002) and assume that a fraction of 0.023 of the $\mathrm{NO}_{\mathrm{x}}$ emitted is heterogeneously converted to HONO. It is worthy to note that the fraction suggested by Gutzwiller et al. (2002) was obtained from diesel exhaust. It might be more appropriate to use the value of $244 \mathrm{mg}$ of secondary HONO formation per $\mathrm{kg}$ of diesel fuel burnt as suggested by Gutzwiller et al. (2002). However, in their experiment, the semivolatile organics in diesel exhaust react with $\mathrm{NO}_{2}$ on time scales of hours, much longer than the time scale of the $\mathrm{NO}_{2}$ to $\mathrm{HONO}$ conversion on freshly soot particles, which is in the order of one minute (Kalberer et al., 1999). Therefore, using the fraction of $\mathrm{NO}_{\mathrm{x}}$ or diesel fuel burnt to calculate the HONO formation is a highly parameterized method based on the experiment of Gutzwiller et al. (2002). In Mexico City, diesel vehicles contribute almost all the organic aerosol emissions (Zavala et al., 2009) and very high levels of organic aerosols have been observed (Aiken et al., 2009), indicating a large amount of semivolatile organics are emitted from diesel vehicles, which could participate in the conversion of $\mathrm{NO}_{2}$ from other sources, such as gasoline engines and biomass burning. Considering the emission contributions from diesel engines and the variation in the fraction of $\mathrm{NO}_{2}$ in $\mathrm{NO}_{\mathrm{x}}$ emissions in Mexico City, the fraction of 0.023 used in the study is likely an upper limit for the $\mathrm{HONO}$ formation from $\mathrm{NO}_{2}$ heterogeneous reaction with semivolatile organics. Furthermore, it is necessary to emphasize that further studies need to be conducted to more appropriately parameterize the $\mathrm{NO}_{2}$ reaction with semivolatile organics.

Ammann et al. (1998) found an efficient conversion of $\mathrm{NO}_{2}$ to HONO on suspended soot particles with a reaction probability ranging from $1.1 \times 10^{-2}$ to $3.3 \times 10^{-4}$, but they did not conclude whether the conversion process is catalytic or not. Subsequently, Kalberer et al. (1999) concluded that the $\mathrm{NO}_{2}$ to $\mathrm{HONO}$ conversion on soot particles rapidly saturates because of consumption of the reactive sites. They suggested an upper limit for HONO formation of $10^{18} \mathrm{HONO}$ molecules $\mathrm{mg}^{-1}$ freshly emitted soot. However, Arens et al. (2001) estimated that the total HONO formation potential of soot particles was about $1.3 \times 10^{17}$ HONO molecules $\mathrm{mg}^{-1}$ of diesel soot, and suggested that the reaction between $\mathrm{NO}_{2}$ and diesel soot particles does not provide a significant secondary HONO source in the atmosphere. We employ the value of $1.3 \times 10^{17} \mathrm{HONO} \mathrm{mg}^{-1}$ of freshly emitted soot to calculate the conversion of $\mathrm{NO}_{2}$ to HONO based on the black carbon emissions in the WRFCHEM model, considering that the reaction rate of $\mathrm{NO}_{2}$ with freshly emitted soot is dramatically reduced after the first seconds (Kalberer et al., 1999), which is less than the chemical integration time step in simulations.

Several heterogeneous reactions on different surfaces involving $\mathrm{NO}_{2}$ as a reactant have been proposed as potential contributors to HONO formation in the troposphere (Febo et al., 1987; Svensson et al., 1987; Saliba et al., 2000; Kleffmann et al., 1998; Lammel and Cape, 1996):

$$
\begin{aligned}
& 2 \mathrm{NO}_{2}+\mathrm{H}_{2} \mathrm{O} \rightarrow \mathrm{HONO}+\mathrm{HNO}_{3} \\
& \mathrm{NO}+\mathrm{NO}_{2}+\mathrm{H}_{2} \mathrm{O} \rightarrow 2 \mathrm{HONO} \\
& \mathrm{NO}+\mathrm{HNO}_{3} \rightarrow \mathrm{NO}_{2}+\mathrm{HONO}
\end{aligned}
$$


However, most laboratory studies suggest that the reaction of $\mathrm{NO}_{2}$ to $\mathrm{HONO}$ is first order in $\mathrm{NO}_{2}$ concentration, thus the $\mathrm{HONO}$ formation can be parameterized by the following reactions (Aumont et al., 2003):

$\mathrm{NO}_{2} \rightarrow \mathrm{HONO}, \quad k_{a}$

$\mathrm{NO}_{2} \rightarrow \mathrm{HONO}, \quad k_{g}$

Where, $k_{a}$ and $k_{g}$ are the first order rate constants for aerosol and ground surface reactions, respectively.

For the reaction on aerosols, the first order rate constant $k_{a}$ is estimated by

$k_{a}=\frac{1}{4} v_{\mathrm{NO}_{2}}\left(\frac{S}{V}\right) r_{a}$

where $v_{\mathrm{NO}_{2}}$ is the mean molecular speed of $\mathrm{NO}_{2}, S / V$ is the surface to volume ratio, and $r_{a}$ is the reactive uptake coefficient. We use a low value of $r_{a}=1 \times 10^{-6}$ in the nighttime (Aumont et al., 2003) and increase it to $5 \times 10^{-6}$ in the daytime with the assumption that aerosols are mixed or covered with organic compounds, humid acids, soot or dust, which dramatically enhance the HONO formation when the sunlight is available (George, 2005; Stemmler et al., 2007; Monge et al., 2010; Ndour et al., 2008). With regard to the $\mathrm{NO}_{2}$ reaction on ground surface, the rate constant is calculated by

$k_{g}=\frac{1}{8} v_{\mathrm{NO}_{2}}\left(\frac{S}{V}\right) r_{g}$

where $r_{g}$ is the reactive uptake coefficient of ground surface. According to tunnel measurements and experiments by Kurtenbach et al. (2001), we use a value of $r_{g}=1 \times 10^{-6}$ at the nighttime. Stemmler et al. (2006) showed that $\mathrm{NO}_{2}$ is effectively reduced to HONO on light activated surfaces containing humic acids, soils or selected synthetic aromatic compounds. The dust and soot particles deposited on the ground surface also enhance the HONO production when the sunlight is available (Ndour et al., 2008; Monge et al., 2010). A relatively large uptake coefficient of $2 \times 10^{-5}$ is suggested, with dependence on the light intensity. When the sunlight is available and the light density is less than $400 \mathrm{~W} \mathrm{~m}^{-2}$, the uptake coefficient is set to $2 \times 10^{-5}$. When the light density is more than $400 \mathrm{~W} \mathrm{~m}^{-2}$, the uptake coefficient of $2 \times 10^{-5}$ is scaled by a factor defined as (light density)/400. We use an effective surface of $1.7 \mathrm{~m}^{2}$ per geometric surface in the model surface layer to calculate the surface to volume ratio (Vogel et al., 2003).

\subsection{Model configuration}

Two three-day episodes from 24 to 26 and from 27 to 29 March 2006 are selected in the present study, representing typical "O${ }_{3}$-Convection South" and " $\mathrm{O}_{3}$-Convection North" meteorological conditions in Mexico City, respectively (de

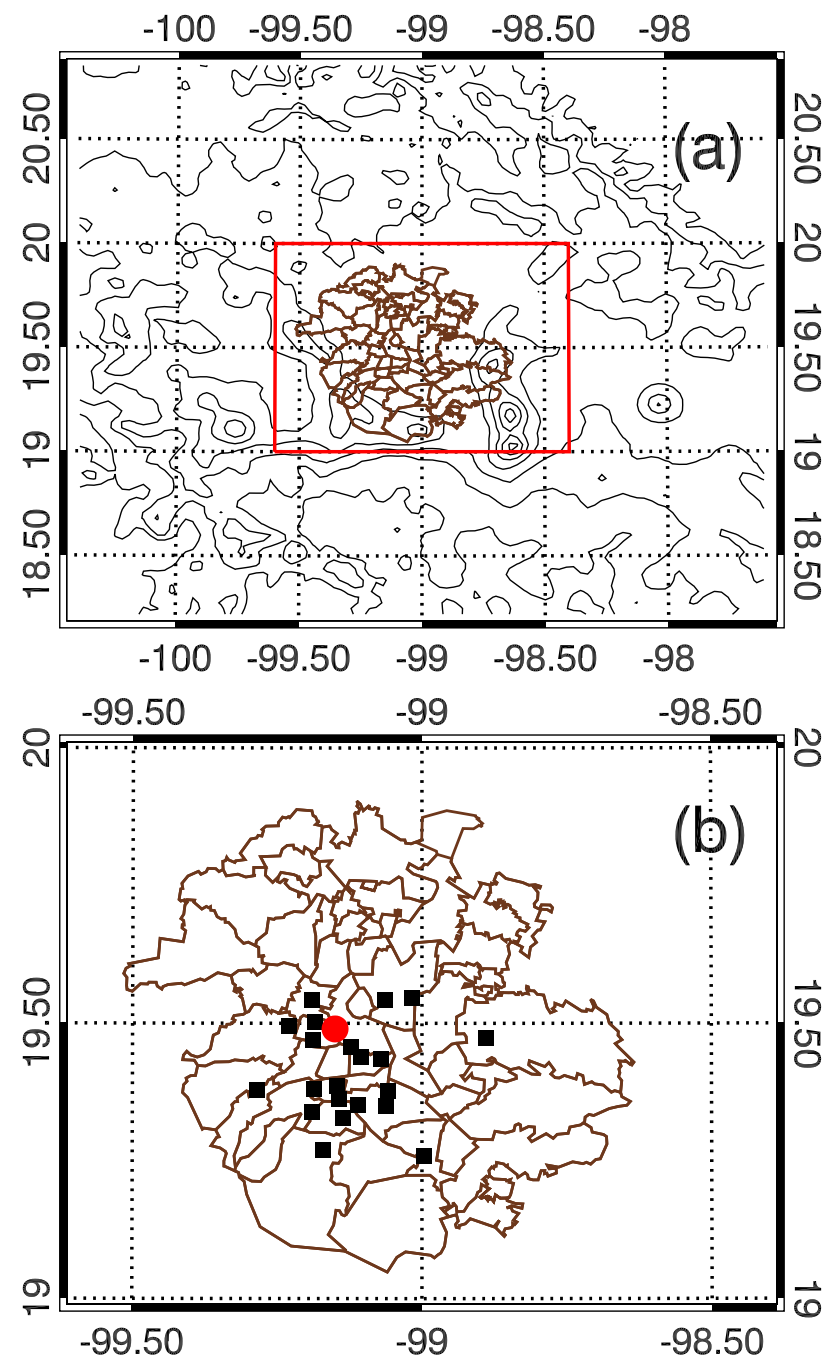

Fig. 1. WRF-CHEM simulation domain. Black squares represent the RAMA (Mexico City Ambient Air Monitoring Network) sites and red filled circle is the T0 super site at the Instituto del Petroleo (IMP) laboratories (Mexico, DF).

Foy et al., 2008). The WRF-CHEM model is configured with one grid with spacing of $3 \mathrm{~km}(99 \times 99$ grid points $)$ centered at $19.538^{\circ} \mathrm{N}$ and $99^{\circ} \mathrm{E}$ (Fig. 1). Thirty-five vertical levels are used in a stretched vertical grid with spacing ranging from $50 \mathrm{~m}$ near the surface, to $500 \mathrm{~m}$ at $2.5 \mathrm{~km}$ Above Ground Level (AGL) and $1 \mathrm{~km}$ above $14 \mathrm{~km}$. The modeling system employs the microphysics scheme of Lin et al. (1983), the Yonsei University (YSU) PBL scheme (Noh et al., 2001), the Noah land-surface model (Chen and Dudhia, 2000), the RRTM longwave radiation parameterization (Mlawer et al., 1997), and a shortwave radiation parameterization (Dudhia, 1989). Meteorological initial and boundary conditions are from NCEP $1^{\circ} \times 1^{\circ}$ reanalysis data. Chemical initial and boundary conditions are interpolated from MOZART 3-h output (Horowitz et al., 2003). 


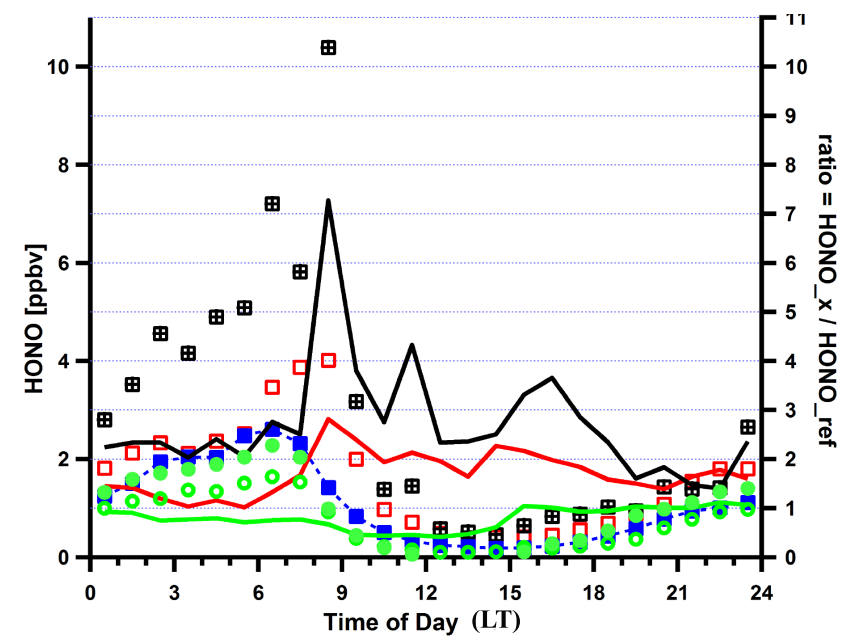

Fig. 2. Comparison of HONO measurements from three LPDOAS instruments during two field campaigns in the MCMA. (open circles) HONO mean concentration during MCMA-2003 from DOAS\#2 at $70 \mathrm{~m}$ above ground; (solid circles) MCMA-2003 mean from DOAS\#1 at $18 \mathrm{~m}$ above ground; (solid squares with dashed line) reference case: MCMA-2006 mean, excluding data from the model period (24-29 Apri), data measured $16 \mathrm{~m}$ above ground; (open squares) mean during the model period (24-29 April); (crossed squares) data from 29 April 2006. Also shown on the right scale are ratios of HONO concentrations for data subsets: (green line) MCMA-2003 average of two DOAS instruments, divided by reference case; (red line) model period divided by reference case; (black line) 29 April 2006 divided by the reference case.

Two case simulations are performed in this study. In the homogeneous case (hereafter referred to as $\mathrm{H}$-case), only the gas phase reaction of $\mathrm{NO}$ with $\mathrm{OH}$ is considered as the HONO source. For the enhanced case (hereafter referred to as E-case), the four HONO sources described in Section 2.2 are included together with the gas phase reaction. We compare the model results from the H-case and E-case with measurements obtained at the T0 urban supersite (Table 1). In addition, based on the E-case, several experimental studies have been performed to verify the HONO contribution from the photolysis of different ortho-nitrophenols and evaluate the sensitivity of HONO sources to the input parameters.

\section{Results}

\subsection{HONO measurements}

Figure 2 compares diurnal profiles of HONO concentrations measured by LP-DOAS during the MCMA-2003 and MCMA-2006 field campaigns. Two LP-DOAS instruments were deployed at a mean height of $16 \mathrm{~m}$ and $70 \mathrm{~m}$ above ground at CENICA during MCMA-2003 (Volkamer et al., 2007). During MCMA-2006, the LP-DOAS was located at about $14 \mathrm{~m}$ above ground at T0. Mean diurnal profiles are shown for the entire campaign duration for the two instruments from MCMA-2003, and for different data subsets for MCMA-2006. We define the reference case as the mean diurnal profile calculated from measurements for all MCMA2006 campaign days except the modeling period. If measurements are compared at a comparable mean height of the LPDOAS light path above ground, the mean HONO diurnal profiles during MCMA-2003 and the reference case agree within $10 \%$ at night. Somewhat larger differences are observed during daytime, with up to $50 \%$ lower daytime HONO observed during MCMA-2003 compared to the reference case. Vertical concentration gradients can explain up to $40 \%$ lower HONO at $70 \mathrm{~m}$ compared to $16 \mathrm{~m}$ above ground at night during MCMA-2003; this is consistent with HONO formation on urban surfaces as it has been invoked in other studies (Olaguer et al., 2009). The onset of convective vertical mixing of air shortly after sunrise quickly reduced any vertical concentration gradients of HONO in the early morning, and no evidence for vertical gradients was observable $2-3 \mathrm{~h}$ after sunrise during MCMA-2003. Figure 2 shows that on a mean basis the combination of horizontal and vertical HONO gradients can explain a variability of up to $50 \%$ in HONO between the reference case and the MCMA-2003 data.

During the period from 24-29 April 2006 HONO was systematically higher than could be explained based on typical concentration gradients. While nighttime HONO agreed reasonably well with that observed in the reference scenario (with the exception of April 29), significantly higher HONO was observed primarily during daytime. The mean daytime HONO during 24-29 April was 2-3 times higher than during the rest of the MCMA-2006 field campaign, and 4-5 times higher than during MCMA-2003. Differences were particularly large on 29 April when nighttime HONO was 23 times higher, and daytime $\mathrm{HONO}$ was up to 7 times higher than observed during the reference scenario. The largest enhancement in daytime HONO over the reference case was observed in the mid-morning, but differences persisted for most of the day. This modeling paper does not attempt to explain why periods of enhanced daytime HONO are observed in the MCMA. Rather, the focus is on the study of the role that such periods can play to accelerate the formation of secondary pollutants such as ozone and secondary aerosol formation within the MCMA. However, it should be emphasized that no events of elevated daytime HONO were observed during MCMA-2003 (Volkamer et al., 2007), and for the most part of MCMA-2006. The frequency with which events of enhanced daytime HONO occur within the MCMA is presently not well established.

\subsection{HONO simulations}

Figure 3 shows the diurnal variation of the modeled HONO concentrations in the H-case and E-case compared with the measurement at T0 from 24 to 29 March 2006. In the Hcase with only the gas phase reaction as the HONO source, 
Table 1. Species used for comparison with simulations at T0.

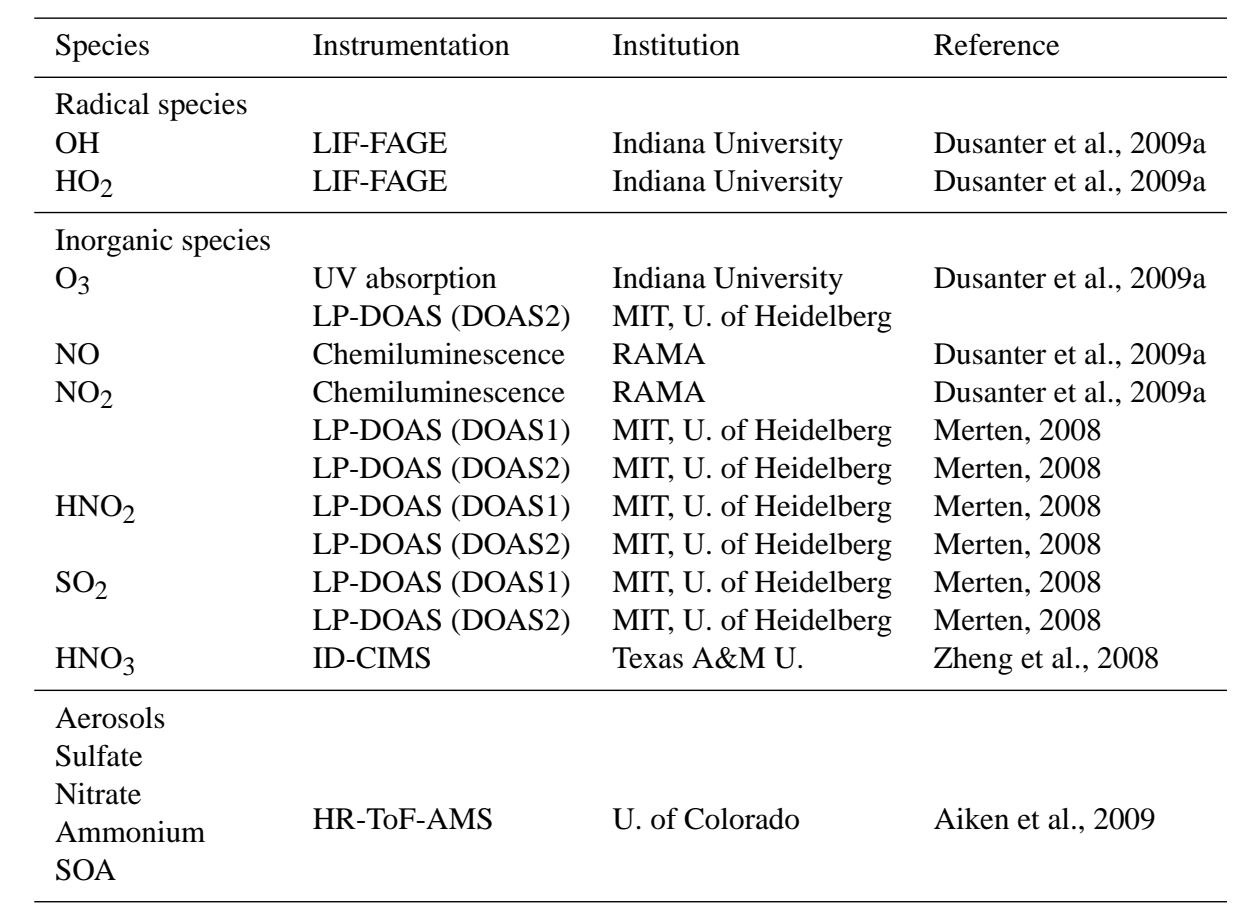

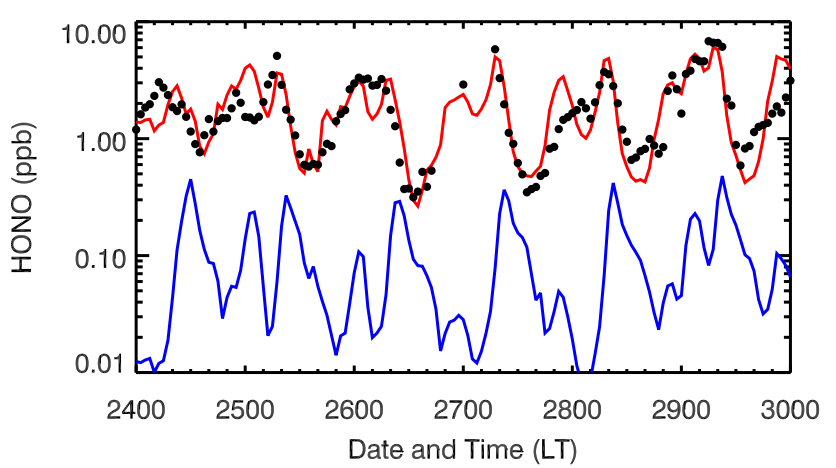

Fig. 3. Simulated and observed HONO at T0 during 24-29 March 2006. The black dots denote the observation, and the red and blue lines represent the simulations in the E-case and H-case, respectively.

the HONO concentrations are underestimated by a factor of 10 on average compared with the observations, particularly during nighttime. The simulation results are fairly consistent with previous studies, which show that the pure gas phase reaction fails to explain the observed high HONO concentrations (Aumont et al., 1999; Stafelbach et al., 1997; Vogel et al., 2003). Additionally, the $\mathrm{RO}_{\mathrm{x}}\left(\mathrm{OH}+\mathrm{HO}_{2}+\mathrm{RO}_{2}\right)$ modeling study for T0 performed by Dusanter et al. (2009b) using a box model has also demonstrated a systematic underprediction of the measured HONO concentrations during daytime if only the homogeneous gas-phase reaction is considered as the HONO source. Moreover, the simulated peak HONO concentrations in the H-case occur at 09:00 LT (local time), one or two hours later than the observed value.

When the four additional sources of HONO are considered in the E-case, the WRF-CHEM model tracks reasonably well the HONO diurnal variability compared with the measurement. For example, the occurrence of peak HONO concentrations is well replicated, and the accumulation of nighttime HONO concentrations and the rapid falloff of morning HONO concentrations are also reproduced. However, the E-case frequently underestimates the HONO levels during the afternoon, particularly on 28 and 29 March indicating either unawareness of unknown sources or uncertainties from meteorological field simulations. For example, Zhou et al. (2002) speculated that the photolysis of $\mathrm{HNO}_{3}$ might contribute significantly to the missing daytime HONO sources. In the simulations of Vogel et al. (2003), although the direct emission of $\mathrm{HONO}$ and the $\mathrm{NO}_{2}$ heterogeneous reaction on aerosol and ground surfaces were included, the simulated daytime HONO concentrations were also underestimated by 30-50\% compared with the observations. An artificial photolytic HONO source had to be introduced in order to improve the HONO simulations during daytime.

In the present study, a photochemical source of HONO on ground surfaces has been incorporated into the WRFCHEM model with a relatively large uptake coefficient. Additionally, in the HONO parameterization, we do not include the HONO production from the photolysis of different 


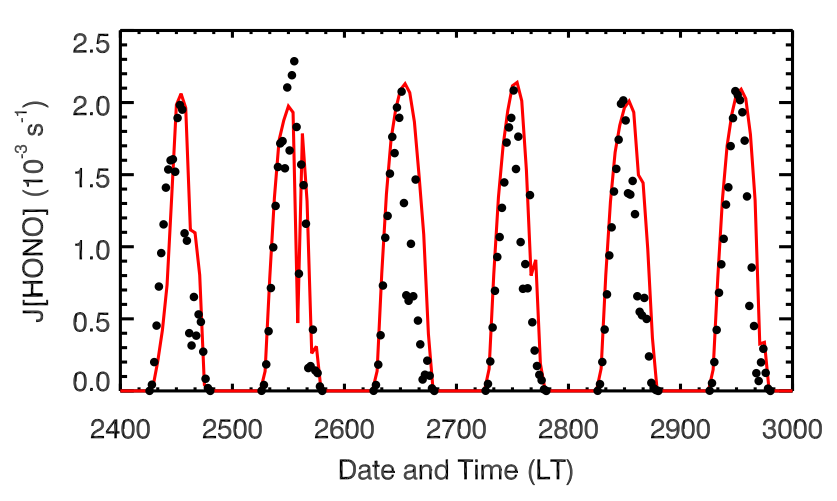

Fig. 4. Simulated and observed photolysis rate of HONO at TO during 24-29 March 2006. The black dots denote the observation and the red represents the simulations in the E-case.

ortho-nitrophenols (Bejan et al., 2006; Kleffmann, 2007), because all nitrophenols are represented by one lumped species (NPHE) in the SAPRC 99 mechanism and the absorption cross section of ortho-nitrophenols is not available yet. In order to evaluate possible HONO contribution from the photolysis of different ortho-nitrophenols, we have conducted a sensitivity study in the E-case, assuming that all nitrophenols are photolyzed to form HONO and the photolysis frequency is interpolated from $J\left[\mathrm{NO}_{2}\right]$ as suggested by Bejan et al. (2006). The study provides an upper limit of HONO production from the photolysis of different orthonitrophenols. The enhancement of HONO concentrations from the photolysis of nitrophenols is less than 3 ppt on average during daytime, which is probably due to the low level of predicted nitrophenols (less than $0.3 \mathrm{ppb}$ ) in the simulation. Therefore, the photolysis of ortho-nitrophenols is less likely to be a significant HONO source in Mexico City.

Meteorological conditions play also a key role in air pollution simulations principally through determining the dispersion or accumulation of pollutant emissions and also influencing their lifetime via changing chemical processes (Bei et al., 2008). Convections were active during the period from 24 to 29 March (de Foy et al., 2009), which may significantly influence the HONO simulation in the WRF-CHEM model. The frequent cumulus cloud formation and development remarkably affect the photolysis rates of HONO. Figure 4 presents the comparison of the observed and simulated photolysis rates of $\mathrm{HONO}$ at $\mathrm{T} 0$. The photolysis rates for HONO were directly measured using a spectroradiometer at T0 (Volkamer et al., 2007). The reduction of HONO photolysis rates due to clouds is salient in the afternoon during the two episodes, particularly on 28 and 29 March. However, unfortunately, the WRF-CHEM model frequently fails to resolve the formation and development of cumulus clouds using 3-km horizontal resolution. Therefore, in the afternoon, the WRF-CHEM model often overestimates the HONO photolysis rates, and likely underestimates HONO concentra-
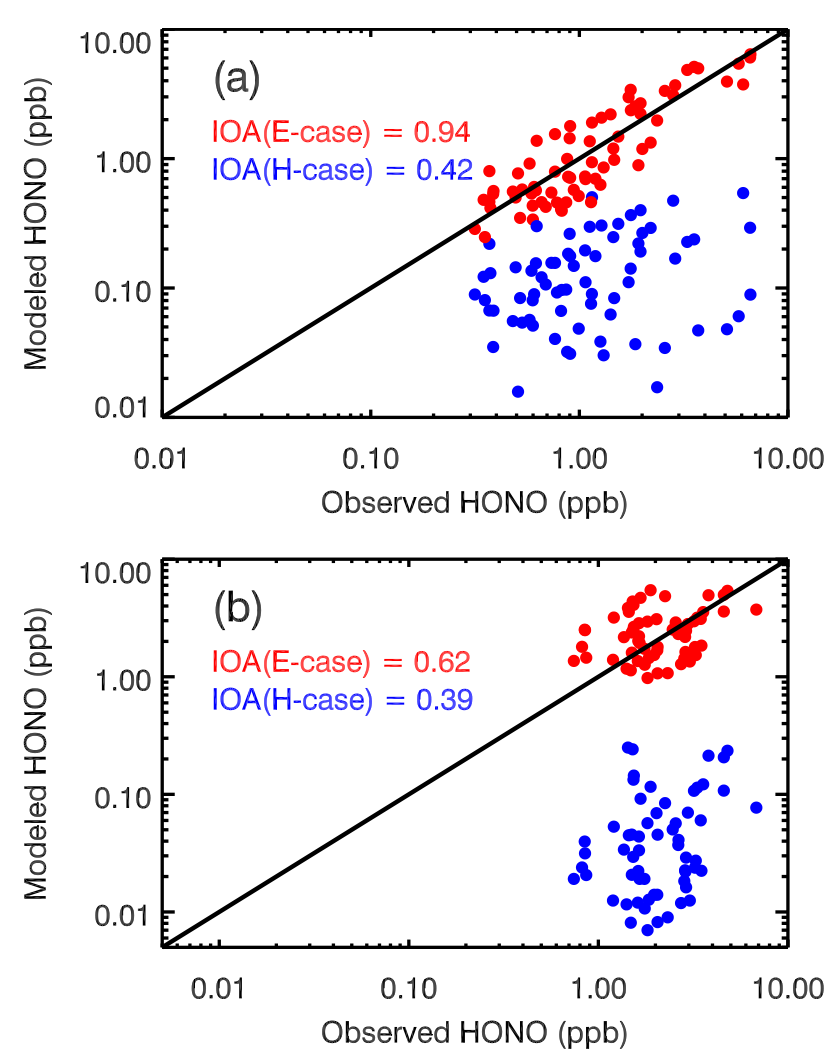

Fig. 5. Comparison between simulated and observed HONO at T0 during (a) daytime and (b) nighttime. The red and blue dots represent the simulations in the E-case and H-case, respectively.

tions during that time. Moreover, the uncertainties in the parameterization of HONO sources used in the study also influence the HONO simulations.

Figure $5 \mathrm{a}$ and $\mathrm{b}$ present the comparisons between simulated and observed HONO concentrations (hourly averaged) during nighttime and daytime. In order to further evaluate the performance of the HONO simulation in the H-case and E-case against the measurements at $\mathrm{T} 0$, an "index of agreement" (IOA) to describe the relative difference between the model and observation is calculated during nighttime and daytime (Willmott and Wicks, 1980). IOA is defined as:

$\mathrm{IOA}=1-\frac{\sum_{i=1}^{N}\left(p_{i}-o_{i}\right)^{2}}{\sum_{i=1}^{N}\left(\left|p_{i}-\bar{o}\right|+\left|o_{i}-\bar{o}\right|\right)^{2}}$

where $p_{i}$ and $o_{i}$ are the simulated and observed variable, respectively. $N$ is the number of cases and $\bar{o}$ denotes the average of the observation. The model index ranges from 0 to 1 , with 1 indicating perfect agreement between model and observation. During daytime, the IOA in the E-case is 0.94, showing good performance in the HONO simulation in the E-case. However, the E-case has difficulties in the nighttime 
HONO simulations, with IOA of 0.62 . In contrast, irregardless of daytime or nighttime, the small IOA in the H-case shows the failure of the homogeneous source to interpret the observed high levels of HONO.

The most important HONO source in the E-case is the secondary $\mathrm{HONO}$ formation from $\mathrm{NO}_{2}$ reaction with semivolatile organics, contributing about $75 \%$ of the HONO concentrations near the ground level during daytime. When a large reactive uptake coefficient is used during daytime, the ground surface also plays an important role in the HONO formation, providing $18 \%$ of the HONO concentrations in the surface level. The contribution from the reaction of $\mathrm{NO}_{2}$ with the freshly emitted soot is small, less than $2 \%$. The model simulations conducted by Aumont et al. (1999), which considered the deactivation of fresh soot surfaces, also showed that the $\mathrm{NO}_{2}+$ soot reaction is not a significant atmospheric source of HONO (Arens et al., 2001). The simulated maximum aerosol surface to volume ratio $(S / V)$ exceeds $1.0 \times 10^{-3} \mathrm{~m}^{-1}$, due to the high pollution in Mexico City. We have used a relatively higher $\mathrm{NO}_{2}$ reaction probability on aerosol surfaces during daytime, but the contribution of HONO at the aerosol surface is still negligible compared to the ground surface, which is in good agreement with the results obtained by Vogel et al. (2003).

Near the ground level, the contribution of HONO from the homogeneous source in the E-case is about 5\% during daytime, which is inconsistent with the results presented by Dusanter et al. (2009b). Using a box model constrained by measurements at T0, they calculated the loss rate of HONO from photolysis to be $11.4 \times 10^{6}$ molecule $\mathrm{cm}^{-3} \mathrm{~s}^{-1}$ while the production rate from $\mathrm{OH}+\mathrm{NO}$ is $6.5 \times 10^{6}$ molecule $\mathrm{cm}^{-3} \mathrm{~s}^{-1}$ on average between 08:40 a.m. and 18:40 LT. They concluded that the homogeneous source accounts for more than $50 \%$ of the HONO formation rate during this time period. In the WRF-CHEM model, HONO is transported and dispersed due to its relatively long lifetime ranging from half an hour in the early morning to around $10 \mathrm{~min}$ at noontime. Particularly, HONO is efficiently mixed in the PBL by the vertical turbulent exchange. The HONO sources of secondary HONO formation from $\mathrm{NO}_{2}$ reaction with semivolatile organics and $\mathrm{NO}_{2}$ reactions with the freshly emitted soot and ground surface are all included in the surface level in the WRF-CHEM model, hence the three sources play a dominant role in the ground level. If the three sources are assumed to be distributed in the PBL, and considering that the simulated mean PBL height between 08:40 and 18:40 LT is about $1.5 \mathrm{~km}$ and the height of the model ground level is about $50 \mathrm{~m}$, the homogeneous source contributes more than $50 \%$ to the HONO production, comparable to the box model results from $\mathrm{Du}$ santer et al. (2009b).

As the most important HONO source in the surface level, the $\mathrm{NO}_{2}$ reaction with the semivolatile organics is highly parameterized in the simulations, using a fraction of 0.023 of the $\mathrm{NO}_{\mathrm{x}}$ emitted to calculate the HONO formation. Based on the experiment of Gutzwiller et al. (2002), the semivolatile organics in diesel exhaust react with $\mathrm{NO}_{2}$ within hours under the condition of sufficient water content. Considering the massive emissions of semivolatile organics from diesel vehicles in Mexico City and the high relative humidity due to convective activities during the simulation period, the fraction of 0.023 used is reasonable, which is demonstrated by the comparison of the simulations in the E-case with the observations at T0. However, the parameterization of the $\mathrm{NO}_{2}$ reaction with the semivolatile organics in the study might not be fit for moderately polluted areas where the emissions of semivolatile organics are not high enough. Further studies are needed to directly parameterize the $\mathrm{NO}_{2}$ reaction with semivolatile organics in models. The uncertainty of the effective surface used in the WRF-CHEM model may also considerably influence the simulated HONO levels because the ground surface plays an important role in the HONO formation in the surface layer. In addition, the HONO formation from $\mathrm{NO}_{2}$ reaction with freshly emitted soot remains highly uncertain, ranging from $1.3 \times 10^{17}$ to $10^{18} \mathrm{HONO}$ molecules $\mathrm{mg}^{-1}$ freshly emitted soot and also depending on the water content (Kalberer et al., 1999; Arens et al., 2001).

We have performed three experimental studies to evaluate the sensitivities of HONO concentrations to the parameters in the above three sources based on the E-case. In the first study, we used a fraction of 0.013 of the emitted $\mathrm{NO}_{\mathrm{x}}$ to parameterize $\mathrm{NO}_{2}$ reaction with semivolatile organics in the E-case. The simulated HONO concentrations are decreased by about $0.67 \mathrm{ppb}$ or $34 \%$ on six-day average at $\mathrm{T} 0$ when the fraction of the emitted $\mathrm{NO}_{\mathrm{x}}$ is reduced from 0.023 to 0.013 . In the second study, when only the effective surface is increased $50 \%$ in the E-case, the HONO concentrations are increased by $0.16 \mathrm{ppb}$ or $8 \%$ on average at $\mathrm{T} 0$, and the simulations in the afternoon are improved but overestimations frequently occur in the morning. When the value of $10^{18} \mathrm{HONO} \mathrm{mg}^{-1}$ of freshly emitted soot is used to calculate the conversion of $\mathrm{NO}_{2}$ to $\mathrm{HONO}$ in the E-case, the HONO concentrations are enhanced by about $0.13 \mathrm{ppb}$ or $7 \%$ on average at $\mathrm{T} 0$, and the $\mathrm{NO}_{2}$-soot reaction become a non-negligible $\mathrm{HONO}$ source.

As discussed above, there are large uncertainties in the HONO simulations due to its poorly understood formation mechanisms, especially during daytime. However, the additional sources in the E-case yield fairly good agreement with the measurement generally. Hence, based on the parameterization, we will evaluate the impact of HONO sources on the photochemistry in the following section.

\subsection{Impacts on $\mathrm{HO}_{\mathrm{x}} / \mathrm{NO}_{\mathrm{x}} / \mathrm{O}_{3}$ chemistry}

In the polluted urban atmosphere, the major reactions that are responsible for the $\mathrm{O}_{3}$ formation can be described as follows (Brasseur et al., 1999):

$$
\begin{aligned}
& \mathrm{OH}+\mathrm{RH} \rightarrow R+\mathrm{H}_{2} \mathrm{O} \\
& R+\mathrm{O}_{2}+M \rightarrow \mathrm{RO}_{2}+M
\end{aligned}
$$




$$
\begin{aligned}
& \mathrm{RO}_{2}+\mathrm{NO} \rightarrow \mathrm{RO}+\mathrm{NO}_{2} \\
& \mathrm{RO}+\mathrm{O}_{2} \rightarrow \mathrm{HO}_{2}+R^{\prime} \mathrm{CHO} \\
& \mathrm{HO}_{2}+\mathrm{NO} \rightarrow \mathrm{OH}+\mathrm{NO}_{2} \\
& 2\left(\mathrm{NO}_{2}+h v \rightarrow \mathrm{NO}+\mathrm{O}\right) \\
& 2\left(\mathrm{O}+\mathrm{O}_{2}+\mathrm{M} \rightarrow \mathrm{O}_{3}+\mathrm{M}\right)
\end{aligned}
$$

Overall:

$$
\mathrm{RH}+4 \mathrm{O}_{2}+h v \rightarrow R^{\prime} \mathrm{CHO}+\mathrm{H}_{2} \mathrm{O}+2 \mathrm{O}_{3}
$$

where RH represents non-methane hydrocarbons, $R^{\prime} \mathrm{CHO}$ denotes carbonyl products, and $R^{\prime}$ designates an organic fragment having one carbon atom fewer than $\mathrm{R}$. The $\mathrm{OH}$ plays a key role in the initialization of the $\mathrm{O}_{3}$ formation process. The most important primary sources of $\mathrm{OH}$ in the polluted atmosphere includes the reaction of $\mathrm{H}_{2} \mathrm{O}$ with $\mathrm{O}\left({ }^{1} \mathrm{D}\right)$ which comes from the photolysis of $\mathrm{O}_{3}$, the reaction of $\mathrm{O}_{3}$ with alkenes and biogenic VOCs-like isoprene and monoterpenes, and the photolysis of HONO. When the additional HONO sources are considered in the WRF-CHEM model, the $\mathrm{OH}$ concentration will be increased to further impact the $\mathrm{HO}_{2} / \mathrm{RO}_{2}$ concentration, the $\mathrm{NO} / \mathrm{NO}_{2}$ partition, and the $\mathrm{O}_{3}$ formation.

Due to the variability and uncertainties of observed $\mathrm{HO}_{\mathrm{x}}$ the six-day averaged modeled and observed $\mathrm{HO}_{\mathrm{x}}$ (2-h averaged for $\mathrm{OH}$ and 1-h averaged for $\mathrm{HO}_{2}$ ) at $\mathrm{T} 0$ are presented in Fig. 6. Although the WRF-CHEM model follows well the variation of $\mathrm{OH}$ concentrations, it underestimates the $\mathrm{OH}$ concentrations in the late morning and early afternoon, regardless of whether the HONO sources are considered. However, when the HONO sources are accounted for, the simulation of $\mathrm{OH}$ concentrations in the E-case substantially improves compared to the measurement, especially in the morning. The E-case yields about $86 \%$ of the observed $\mathrm{OH}$ concentration averaged during the daytime from 08:00 to 18:00 LT; but in the H-case, the simulated $\mathrm{OH}$ concentration is only about $52 \%$ of the observation on average. In addition, the HONO sources play a dominant role in the $\mathrm{OH}$ concentration in the morning, consistent with previous model results (Aumont et al., 2003; Vogel et al., 2003). The inclusion of the HONO sources in the WRF-CHEM model also increases the $\mathrm{HO}_{2}$ concentrations in the E-case, particularly in the early morning and late afternoon, but still underestimates the $\mathrm{HO}_{2}$ concentration by a factor of 2 during noontime (Fig. $5 b$ ). On average, the E-case produces $55 \%$ of the observed $\mathrm{HO}_{2}$ concentration during the daytime from 08:00 to 18:00 LT, but the $\mathrm{H}$-case only simulates $34 \%$ of the observed $\mathrm{HO}_{2}$ concentration. Although the E-case simulates the $\mathrm{HO}_{\mathrm{x}}$ concentrations more consistently with the measurements than the $\mathrm{H}$ case, the modeled $\mathrm{HO}_{2}$ concentrations in the E-case remain about $45 \%$ lower than the observations during daytime, indicating either missing radical sources or incomplete chemical
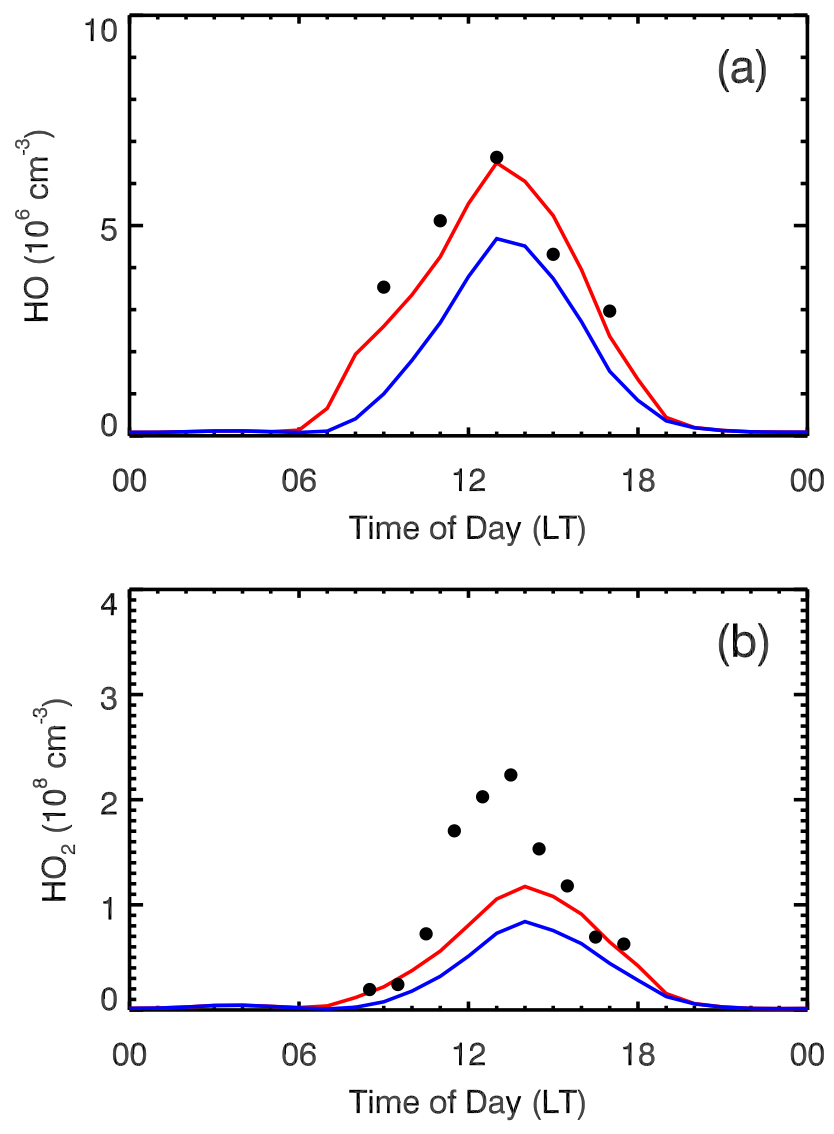

Fig. 6. Influence of the $\mathrm{HONO}$ sources on the (a) $\mathrm{HO}$ and (b) $\mathrm{HO}_{2}$ diurnal cycle at T0 averaged during the 24-29 March 2006. The black dots correspond to the observations, and the solid red and blue lines are the simulations in the E-case and $\mathrm{H}$-case, respectively.

mechanism (Hofzumahaus et al., 2009). The underestimation of VOC concentrations in the model is able to lead to the underestimation of $\mathrm{HO}_{2}$ concentrations. It would cause an underestimation of the reactivity of $\mathrm{OH}$ with VOCs which in turn would result in an underestimation of peroxy radicals. Dusanter et al. (2009b) have calculated a median noontime $\mathrm{OH}$ reactivity of $20-22 \mathrm{~s}^{-1}$ due to VOCs at T0 using a box model, whereas the mean noontime $\mathrm{OH}$ reactivity in the WRF-CHEM model is around $16 \mathrm{~s}^{-1}$. Sheehy et al. (2008) reported that, during MCMA-2003, the measured OH reactivity at noon was about $20-25 \mathrm{~s}^{-1}$, and the MCM box model explained around $20 \mathrm{~s}^{-1}$. Volkamer et al. (2007) also showed that a significant portion of the $\mathrm{HO}_{\mathrm{x}}$ sources is from photolysis of oxygenated VOCs, which may potentially help resolve the lack of peroxy radicals. In addition, the uncertainties from measurements also need to be taken into account when the comparison is performed between simulations and observations. Dusanter et al. (2009a) have reported that the accuracy of the $\mathrm{HO}_{\mathrm{x}}$ measurements is about $18 \%(1 \sigma)$.

The enhancement of $\mathrm{HO}_{2}$ will increase $\mathrm{NO}_{2}$ concentrations and decrease NO concentrations by accelerating the 

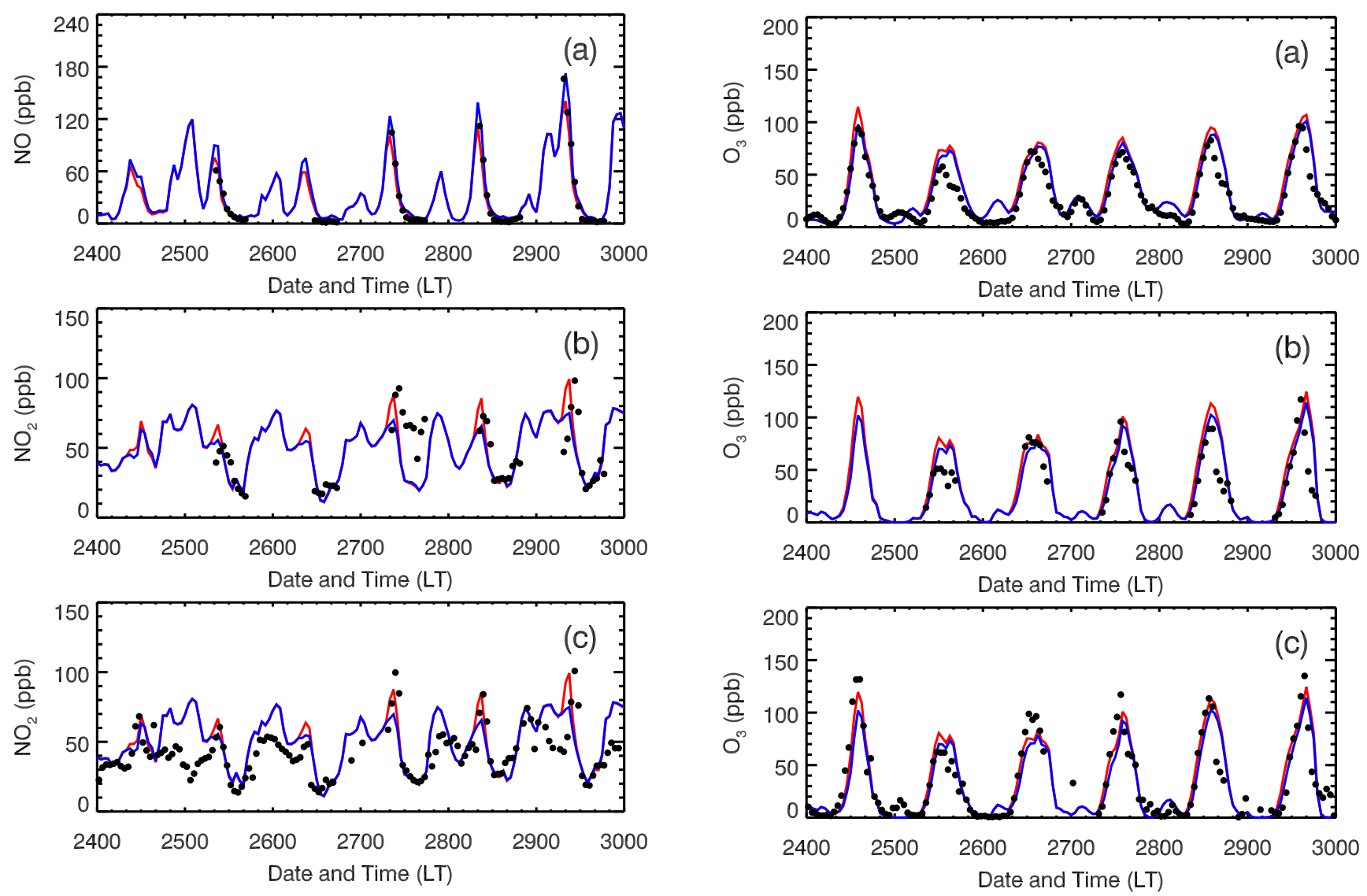

Fig. 7. Simulated and observed (a) $\mathrm{NO}$ and (b), (c) $\mathrm{NO}_{2}$ at $\mathrm{TO}$ during the 24-29 March, 2006. The black dots denote the observation and the red and blue lines represent the simulations in the E-case and $\mathrm{H}$-case, respectively. $\mathrm{NO}_{2}$ measurement in (b) is from Chemiluminescence and (c) is from LP-DOAS.

conversion from $\mathrm{NO}$ to $\mathrm{NO}_{2}$ in the polluted atmosphere. When the four HONO sources are considered, in the early morning, the WRF-CHEM model performs well in the simulation of the NO concentrations compared with the measurement at $\mathrm{T} 0$ in the E-case; the NO concentrations are also considerably reduced compared to that in the H-case (Fig. 7a). However, the WRF-CHEM model overestimates the NO concentrations in the late morning and afternoon in both the Ecase and $\mathrm{H}$-case, which may be caused by the underestimation of $\mathrm{HO}_{2}$ concentrations or other reasons, such as PBL evolution and emission temporal variations. Although the peak $\mathrm{NO}_{2}$ concentrations in the morning are comparable to the measurements in the E-case in Fig. 7b and c, the occurrence of the peak $\mathrm{NO}_{2}$ concentrations is about one hour later than the observation. Without the HONO sources, the $\mathrm{H}$ case substantially underestimates the peak $\mathrm{NO}_{2}$ concentrations from 27 to 29 March. It is worth noting that, on 25 and 26 March, the WRF-CHEM model fails to follow the observed $\mathrm{NO}_{2}$ variation during the nighttime and also significantly overestimates the observation in the early morning,

Fig. 8. Simulated and observed $\mathrm{O}_{3}$ (a) averaged over all RAMA monitoring sites and (b), (c) at T0 site during the 24-29 March 2006. The black dots denote the observation and the red and blue lines represent the simulations in the E-case and $\mathrm{H}$-case, respectively. $\mathrm{O}_{3}$ measurement in (b) is from Chemiluminescence and (c) is from LP-DOAS.

which is probably caused by the failure of boundary layer simulations in these two days.

Figure 8a presents the impact of the HONO sources on the diurnal variation of near-surface $\mathrm{O}_{3}$ concentrations averaged over all monitoring sites from 24 to 29 March 2006. Apparently, the additional HONO sources accelerate the accumulation of $\mathrm{O}_{3}$ concentrations in the morning by about $2 \mathrm{~h}$ generally in the E-case and subsequently result in around $7 \mathrm{ppb}$ enhancement averaged from 08:00 to 14:00 LT. However, during the late afternoon when the HONO sources do not play a dominant role in the $\mathrm{OH}$ production and the plume formed in the morning move out of Mexico City, the $\mathrm{O}_{3}$ increase in the E-case become negligible. The 6-day midday average of $\mathrm{O}_{3}$ enhancement is about $6 \mathrm{ppb}$, which is comparable to the previous CTM study from Lei et al. (2004) in Houston. They included the HONO source from $\mathrm{NO}_{2}$ conversion on the surfaces of soot aerosol in a CTM and found that the HONO source speeds up the build-up of morning $\mathrm{O}_{3}$ concentrations by about $1 \mathrm{~h}$ and leads to an appreciable 

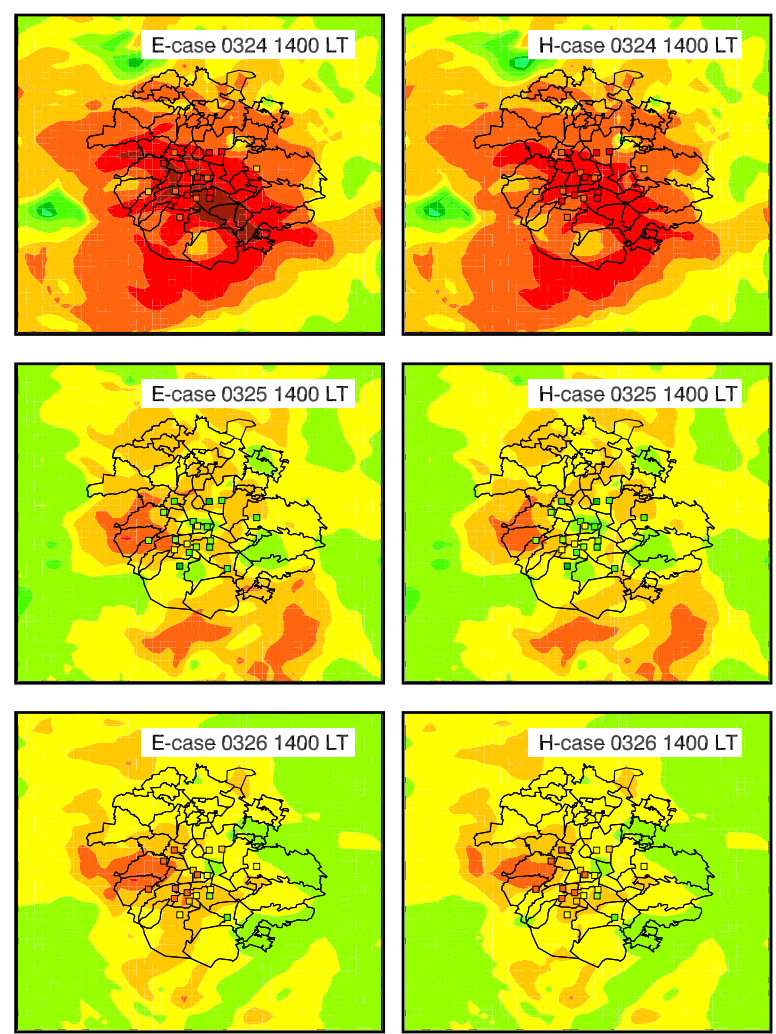

ว 10

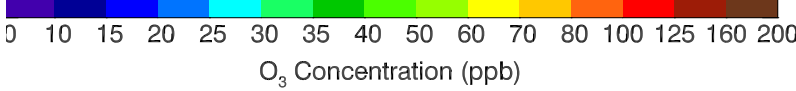

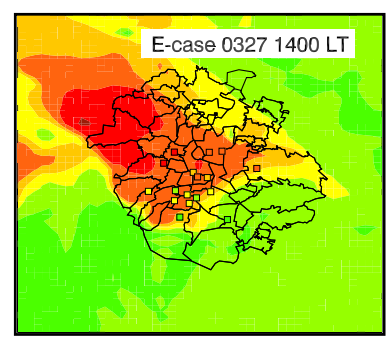
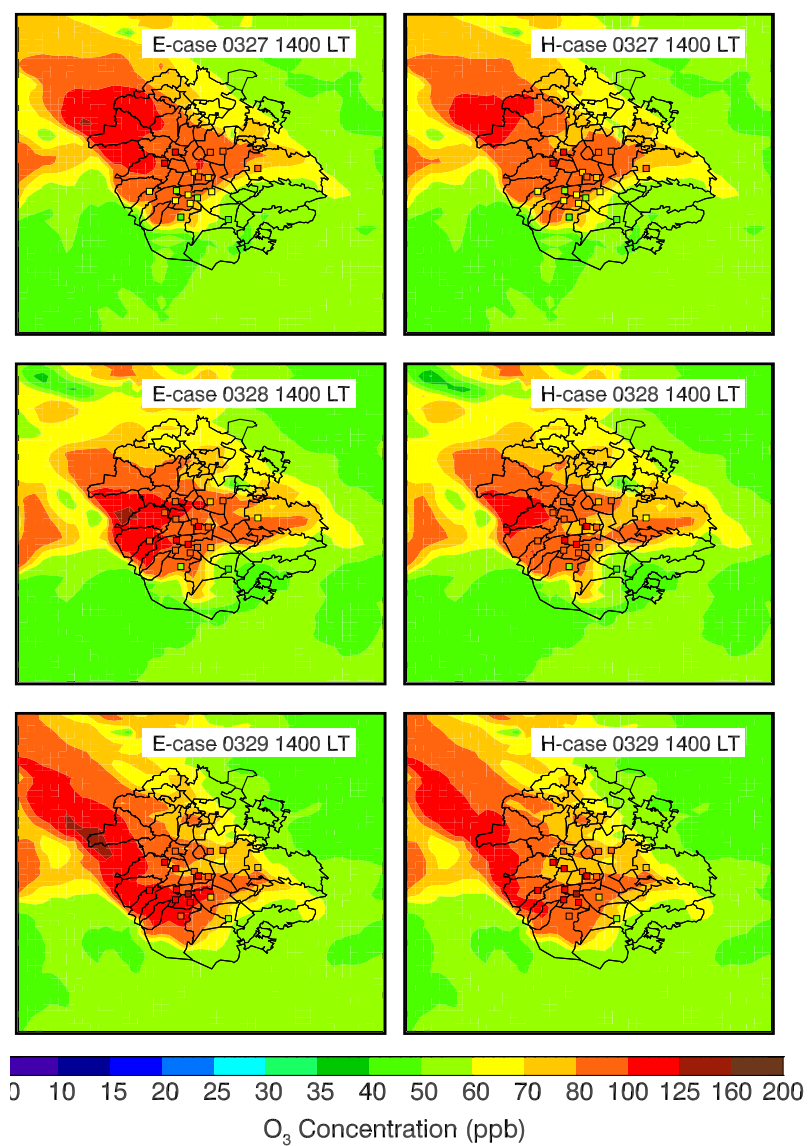

Fig. 9. Pattern comparison of simulated vs. observed $\mathrm{O}_{3}$ at 14:00 LT over Mexico City in the E-case (left) and H-case (right) during the 24-29 March 2006. Colored dots: observations; color contour: simulations.

increase of the $\mathrm{O}_{3}$ concentration over the course of the day with a midday average of $7 \mathrm{ppb}$. In addition, both the E-case and $\mathrm{H}$-case considerably overestimate the $\mathrm{O}_{3}$ concentrations in the late afternoon, which is attributed to the slow movement of the simulated plume and the overestimation of photolysis rates in the afternoon (Fig. 4). Figures $8 \mathrm{~b}$ and c show the comparisons of modeled and observed diurnal variation of $\mathrm{O}_{3}$ concentrations at $\mathrm{T} 0$. The results are similar to that at ambient monitoring sites, except that inclusion of the HONO sources in the WRF-CHEM model improves the simulations of peak $\mathrm{O}_{3}$ concentrations. Figure 9 displays the spatial distributions of calculated (in color contours) and observed (in colored dots) near surface $\mathrm{O}_{3}$ concentrations at 14:00 LT in the E-case and $\mathrm{H}$-case, respectively. In general, the simulated and observed $\mathrm{O}_{3}$ patterns are well matched, but, clearly, the predicted plumes moves more slowly than the observation. For example, at 14:00 LT on 27th, the observed plume has moved to the north of Mexico City, but part of the modeled plume remains stagnant in the center of the city. Furthermore, the $\mathrm{HONO}$ sources do not alter the $\mathrm{O}_{3}$ pattern, but considerably enhance the $\mathrm{O}_{3}$ level in the center of the plumes.

\subsection{Impacts on secondary aerosols}

\subsubsection{Secondary organic aerosols}

In the WRF-CHEM model, a traditional 2-product secondary organic aerosol (SOA) module is applied to predict the aerosol distribution and variation. The SOA module accounts for the SOA formation from the oxidation of six primary organic groups (POG): alkanes, alkenes, cresol, high-yield aromatics, low-yield aromatics, and monoterpenes. Ten semivolatile, gaseous SOA precursors (hereafter referred to as to SVOC) are produced via these reactions - two each for olefins, monoterpenes, and aromatics, and one each for alkanes and cresol.

$\mathrm{POG}+$ oxidant $\rightarrow \alpha_{1} \mathrm{SVOC}_{1}+\alpha_{2} \mathrm{SVOC}_{2}$

The oxidants mainly include the $\mathrm{OH}$ radical, the nitrate radical $\mathrm{NO}_{3}$, and $\mathrm{O}_{3}$. The saturation vapor pressures and massbased stoichiometric yield coefficients $\left(\alpha_{i}\right)$ of semi-volatile precursors are obtained from either smog chamber experiments or from published estimates in cases where smog chamber data are unavailable. The SOA is calculated using the method developed by Schell et al. (2001), which was 


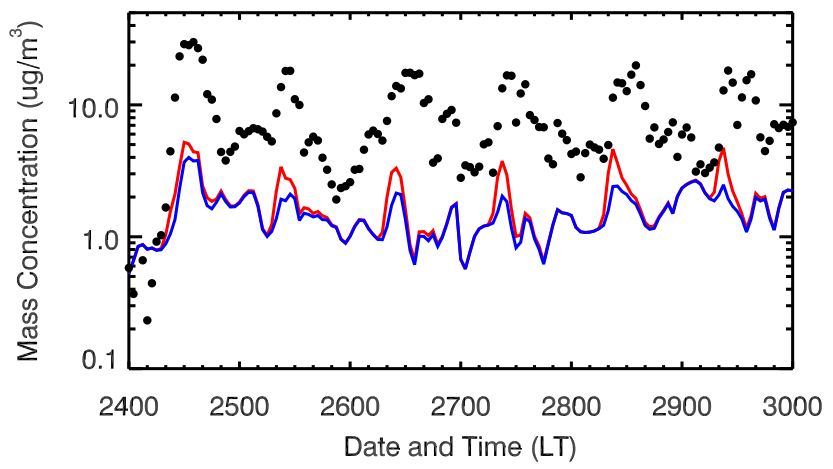

Fig. 10. Simulated submicron SOA and observed submicron OOA at T0 during the 24-29 March 2006. The black dots denote the observation and the red and blue lines represent the simulations in the E-case and H-case, respectively.

based on the absorptive partitioning model of Pankow (1994) that was extended by Odum et al. (1996). When the organic gas/aerosol equilibrium has been established, gas and aerosol-phase concentrations of each SVOC are calculated iteratively using a globally convergent variation of Newton's method. Therefore, the enhancement of the oxidants will augment the production of SVOCs, especially in the morning when the VOCs accumulate in the PBL. The increase of SVOCs is apt to partition more to aerosol phase and further escalate the SOA concentrations.

Figure 10 shows the comparison of submicron modeled SOA and observed OOA diurnal variation at TO. In the morning, the SOA concentrations are substantially enhanced in the E-case compared to the $\mathrm{H}$-case, with an increase of more than $100 \%$ on average. However, during the rest of the day, the enhancement of the SOA concentrations is not very significant, particularly during nighttime. The observed OOA exhibits clearly two peaks around 10:00 and 14:00 LT from 25 to 29 . The E-case and $\mathrm{H}$-case replicates reasonably well these two peaks, but the simulated second peak in the afternoon is not obvious in 25 and 28. Although the E-case yields about $40 \%$ more SOA than the H-case averaged in the six days, both the $\mathrm{E}$-case and $\mathrm{H}$-case significantly underestimate the observed OOA concentrations. The E-case produces about $13 \%$ of the observed OOA concentrations from the oxidation of anthropogenic precursors, consistent with the previous study performed by Volkamer et al. (2006). They reported much larger amounts of SOA formed from reactive anthropogenic VOCs in Mexico City than the estimation from a SOA model based on empirical parameterization of chamber experiments. In addition, although the updated aromatic SOA yields from recent chamber experiments (Ng et al., 2007) have been employed in a photochemical box model study by Dzepina et al. (2009), the traditional 2-product SOA model still fails to yield sufficient SOA concentrations to match the observations by a factor of 7 . Hodzic et al. (2009) also reported that less than $15 \%$ of the observed SOA within Mexico City can be explained by the traditional mechanism based on oxidation of anthropogenic precursors.

The large discrepancies between the modeled SOA and observed OOA concentrations demonstrate that there are other mechanisms that contribute to the SOA formation, in addition to the one used in this study. Robinson et al. (2007) suggested the formation of SOA from primary semivolatile and intermediate volatility species. Dzepina et al. (2009) have shown that the mechanism can help to close the gap in SOA mass between measurements and models in Mexico City. Additionally, Volkamer et al. (2007) pointed out that glyoxal is also a source of SOA. In the future study, we will evaluate the contributions of the above mechanisms to the SOA concentrations.

\subsubsection{Inorganic aerosols}

The inorganic aerosols are predicted in the WRF-CHEM model using ISORROPIA Version 1.7 (http://nenes.eas. gatech.edu/ISORROPIA/). ISORROPIA calculates the composition and phase state of an ammonium-sulfate-nitratechloride-sodium-calcium-potassium-magnesium-water inorganic aerosol in thermodynamic equilibrium with gas phase precursors. The kind of thermodynamic equilibrium is delicately dependent on the environmental humidity and temperature. In this study, ISORROPIA is mainly utilized to predict the thermodynamic equilibrium between the ammoniumsulfate-nitrate-water aerosols and their gas phase precursors of $\mathrm{H}_{2} \mathrm{SO}_{4}-\mathrm{HNO}_{3}-\mathrm{NH}_{3}$-water vapor. Accordingly, the increase of the $\mathrm{OH}$ level due to the HONO sources will impact the inorganic aerosols in the WRF-CHEM model through varying $\mathrm{H}_{2} \mathrm{SO}_{4}$ and $\mathrm{HNO}_{3}$ concentrations.

Figure 11a provides the diurnal variation of $\mathrm{HNO}_{3}$ concentrations in the E-case and $\mathrm{H}$-case compared with the measurements at T0. In the early morning, the E-case and $\mathrm{H}$-case reproduce well the observed slow accumulation of $\mathrm{HNO}_{3}$ concentrations from about $0.01 \mathrm{ppb}$ to $1 \mathrm{ppb}$, but in the afternoon, the WRF-CHEM model overestimates the observation, which is partially caused by the slow movement of the simulated plume. The impacts of the HONO sources on the $\mathrm{HNO}_{3}$ concentrations are insignificant in the morning, although the enhancement of the $\mathrm{OH}$ concentrations due to the HONO sources is supposed to increase the $\mathrm{HNO}_{3}$ concentrations in the E-case. These results indicate that there are sufficient $\mathrm{NH}_{3}$ to balance the enhanced $\mathrm{HNO}_{3}$ into the aerosol phase through the thermodynamic equilibrium. Figure $11 \mathrm{~b}$ shows the comparison of $\mathrm{NH}_{3}$ concentrations between the $\mathrm{E}$ case and $\mathrm{H}$-case at T0. Both the E-case and $\mathrm{H}$-case obtain high levels of $\mathrm{NH}_{3}$ concentrations in the morning and the $\mathrm{NH}_{3}$ concentrations in the E-case are also decreased compared to that in the H-case. Therefore, as shown in Fig. 12, the particle-phase nitrate and ammonium are significantly enhanced in the E-case compared to that in the H-case in the morning. The observed particle-phase nitrate and ammonium show two peaks around 10:00 and 14:00 LT from 25 

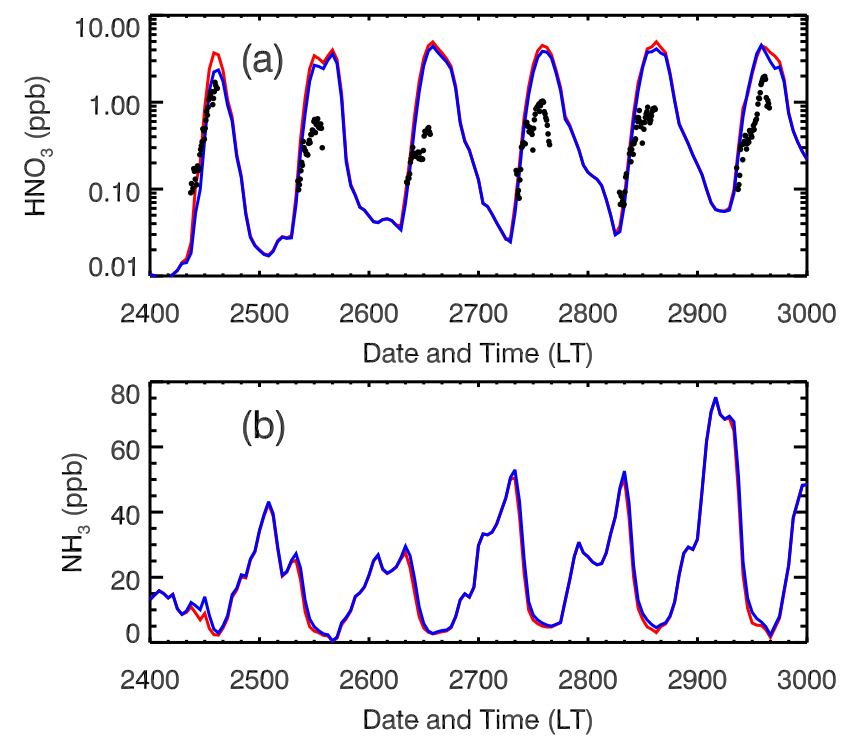

Fig. 11. Same as Fig. 8, except for (a) $\mathrm{HNO}_{3}$ and (b) $\mathrm{NH}_{3}$.

to 29 and the concentrations in the first peak are much higher than those in the second one. When the HONO sources are considered in the E-case, the WRF-CHEM model reasonably well simulates the first peak but remains underestimation from 27 to 29 compared to the observation. In addition, the HONO sources cause overestimation of the first peak on 25 and 26. The particle-phase nitrate and ammonium are increased by almost $100 \%$ in the E-case compared to the $\mathrm{H}$ case in the morning, but the enhancement is not significant in the afternoon; the slow movement of plumes also results in the overestimation of the particle-phase nitrate and ammonium in the late afternoon.

The formation of $\mathrm{H}_{2} \mathrm{SO}_{4}$ in the atmosphere through the gas phase reaction of $\mathrm{SO}_{2}$ with $\mathrm{OH}$ is not efficient due to the slow reaction rate. Therefore, the enhancement of the $\mathrm{OH}$ concentrations due to the HONO sources cannot efficiently convert $\mathrm{SO}_{2}$ into $\mathrm{H}_{2} \mathrm{SO}_{4}$ to increase the sulfate aerosols. Figure 13a displays the diurnal variations of $\mathrm{SO}_{2}$ concentrations in the $\mathrm{E}$-case and $\mathrm{H}$-case compared with the measurement at $\mathrm{T} 0$. The impacts of the HONO sources on the $\mathrm{SO}_{2}$ concentrations are negligible and the reduction of $\mathrm{SO}_{2}$ concentrations in the E-case is less than $1 \%$ during the daytime on average in comparison with that in the $\mathrm{H}$-case. The WRF-CHEM model basically tracks the observed variation of $\mathrm{SO}_{2}$ concentrations during the daytime, but fails to reproduce the large fluctuations of the observations during the afternoon and at night. The impacts of the HONO sources on the sulfate at $\mathrm{T} 0$ are also negligible, indicating that the gas phase reaction of $\mathrm{SO}_{2}$ with $\mathrm{OH}$ plays a minor role in the sulfate formation (Fig. 13b). Other sources, such as the oxidation of $\mathrm{SO}_{2}$ in cloud droplets as well as the transport of direct emissions of sulfate from the Tula industrial complex and the volcano, may play a key role in the sulfate concentrations in Mexico City (de Foy et al., 2009).
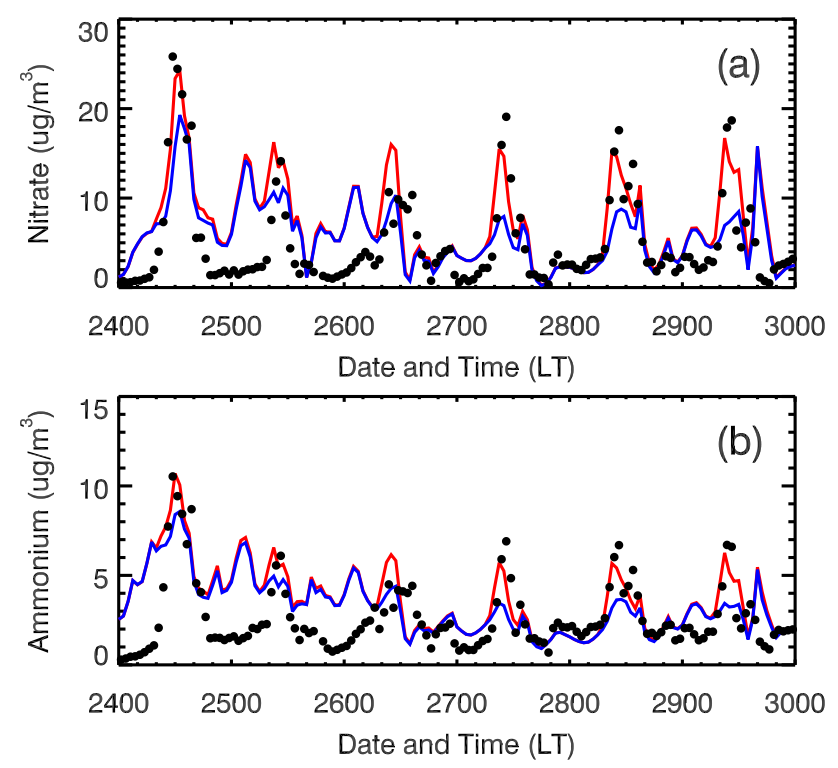

Fig. 12. Same as Fig. 8, except for submicron (a) nitrate and (b) ammonium aerosols.
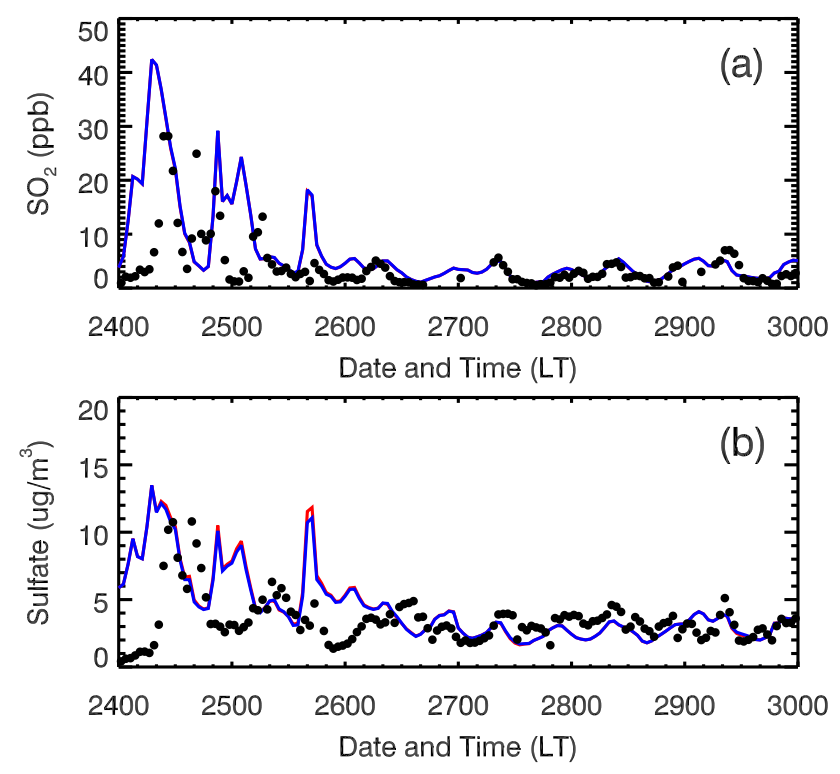

Fig. 13. Same as Fig. 8, except for (a) $\mathrm{SO}_{2}$ and (b) submicron sulfate aerosols.

\section{Conclusions}

The present study investigates the contribution of HONO sources to the photochemistry in Mexico City during the MCMA-2006/MILAGO Campaign using the WRF-CHEM model. In addition to the gas phase reaction of $\mathrm{NO}$ with $\mathrm{OH}$, four additional HONO sources are considered in the WRFCHEM model, including secondary HONO formation from $\mathrm{NO}_{2}$ heterogeneous reaction with semivolatile organics, $\mathrm{NO}_{2}$ 
reaction with freshly emitted soot, $\mathrm{NO}_{2}$ heterogeneous reaction on aerosol and ground surfaces. When only the gas phase reaction is considered, the WRF-CHEM model fails to predict the high levels of HONO concentrations observed at $\mathrm{T} 0$ by a factor of 10 , consistent with previous studies. In contrast, the WRF-CHEM model with the four additional HONO sources performs well in tracking the diurnal variation of the HONO concentrations, although it frequently underestimates HONO concentrations in the afternoon. Quantification of the contribution from individual sources in the ground level shows that secondary HONO formation from $\mathrm{NO}_{2}$ heterogeneous reaction with semivolatile organics is the most important sources in Mexico City, providing about $75 \%$ of the HONO formation. The $\mathrm{NO}_{2}$ reaction on ground surfaces also plays an important role in the HONO formation, with about $18 \%$ contribution near the surface. The contributions from the $\mathrm{NO}_{2}$ reaction with newly emitted soot and heterogeneous reaction on aerosol surfaces is negligible.

Based on the simulations with only the homogeneous reaction and with the additional HONO sources, we evaluate the impacts of the HONO sources on the $\mathrm{HO}_{\mathrm{x}} / \mathrm{NO}_{\mathrm{x}} / \mathrm{O}_{3}$ chemistry and secondary aerosols. When the additional HONO sources are considered, the WRF-CHEM model significantly increases the $\mathrm{HO}_{\mathrm{x}}$ concentration, yielding better agreement with the measurements than if only the gas phase reaction source is considered. Inclusion of additional HONO sources alters the partition of $\mathrm{NO} / \mathrm{NO}_{2}$ and converts more $\mathrm{NO}$ into $\mathrm{NO}_{2}$, particularly in the morning. Although the WRF-CHEM model including the five HONO sources cannot improve the simulations of the occurrence of peak $\mathrm{NO}_{2}$ concentrations, it performs quite well in modeling the NO variability compared to the observations at $\mathrm{T} 0$. The HONO sources accelerate the accumulation of $\mathrm{O}_{3}$ concentrations averaged over all the ambient monitoring sites in the morning by about $2 \mathrm{~h}$ and subsequently lead to a noticeable enhancement of $\mathrm{O}_{3}$ concentrations over the course of the day with a midday average of about $6 \mathrm{ppb}$. The WRF-CHEM model considerably overestimates $\mathrm{O}_{3}$ concentrations in the late afternoon whether the additional HONO sources are considered or not, which is mainly caused by the slow movement of the simulated plumes and overestimation of the photolysis rates.

The HONO sources also play a very important role in the formation of secondary aerosols in the morning. The HONO sources substantially enhance the SOA concentrations by a factor of 2 on average in the morning, but contribute less during the rest of the day. It is worthy to note that the traditional 2-product SOA mechanism fails to predict high levels of SOA mass comparable to the observations at T0, which agrees well with the other studies in Mexico City (Volkamer et al., 2006; Dzepina et al., 2009; Hodzic et al., 2009). The particle-phase nitrate and ammonium are significantly enhanced in the morning when all five HONO sources are included, and agree better with the measurements at T0 compared to the results with only gas phase HONO source. Due to the inefficient conversion of $\mathrm{H}_{2} \mathrm{SO}_{4}$ from $\mathrm{SO}_{2}$ reaction with $\mathrm{OH}$, the impact of the HONO sources to the sulfate aerosols is negligible.

Generally speaking, the HONO sources play an important role in the photochemistry in the morning by enhancing the $\mathrm{OH}$ concentration in Mexico City. If the air quality in the morning is of much concern in urban regions, it may be necessary to include these HONO sources in air quality models. However, except the gas-phase reaction of $\mathrm{NO}$ with $\mathrm{OH}$, the other four HONO sources are all associated with $\mathrm{NO}_{2}$, so the importance of these four HONO sources is dependent on the $\mathrm{NO}_{2}$ level, i.e., there is a $\mathrm{NO}_{\mathrm{x}}$ threshold to activate the importance of these HONO sources.

Furthermore, it is important to emphasize that the model period is not representative of all the MCMA-2006 campaign duration, but rather exemplifies the periods with elevated daytime HONO observed in the MCMA, and that during these periods the formation of secondary pollutants has a particular sensitivity to HONO concentrations. Additionally, meteorological conditions also play a key role in determining the accumulation or dispersion of HONO (as well as other species), also influencing its lifetime via changing chemical processes. Therefore, meteorological conditions significantly influence the evaluation of the impact of $\mathrm{HONO}$ sources on the photochemistry in the polluted urban atmosphere.

Acknowledgements. We are indebted to the large number of people involved in the MILAGRO field campaign as well as those involved in long-term air quality monitoring and the emissions inventory in the Mexico City metropolitan area, which made this study possible. This work was supported by the US National Science Foundation's Atmospheric Chemistry Program (ATM-0528227) and the Molina Center for Energy and the Environment. Acknowledgment is also made to the National Center for Atmos. Res., which is sponsored by the National Science Foundation, for the computing time used in this research.

Edited by: S. Madronich

\section{References}

Acker, K., Möller, D., Auel, R., Wieprecht, W., and Kala, D.: Concentrations of nitrous acid, nitric acid, nitrite and nitrate in the gas and aerosol phase at a site in the emission zone during ESCOMPTE 2001 experiment, Atmos. Res., 74(1-4), 507-524, 2005.

Aiken, A. C., Salcedo, D., Cubison, M. J., Huffman, J. A., DeCarlo, P. F., Ulbrich, I. M., Docherty, K. S., Sueper, D., Kimmel, J. R., Worsnop, D. R., Trimborn, A., Northway, M., Stone, E. A., Schauer, J. J., Volkamer, R. M., Fortner, E., de Foy, B., Wang, J., Laskin, A., Shutthanandan, V., Zheng, J., Zhang, R., Gaffney, J., Marley, N. A., Paredes-Miranda, G., Arnott, W. P., Molina, L. T., Sosa, G., and Jimenez, J. L.: Mexico City aerosol analysis during MILAGRO using high resolution aerosol mass spectrometry at the urban supersite (T0) - Part 1: Fine particle composition and 
organic source apportionment, Atmos. Chem. Phys., 9, 66336653, doi:10.5194/acp-9-6633-2009, 2009.

Alicke, B., Platt, U., and Stutz, J.: Impact of nitrous acid photolysis on the total hydroxyl radical budget during the Limitation of Oxidant Production/Pianura Padana Produzione di Ozono study in Milan, J. Geophys. Res., 107, 8196, doi:10.1029/2000JD000075, 2002.

Alicke, B., Geyer, A., Hofzumahaus, A., Holland, F., Konrad, S., Pätz, H. W., Schäfer, J., Stutz, J., Volz-Thomas, A., and Platt, U.: $\mathrm{OH}$ formation by HONO photolysis during the BERLIOZ experiment, J. Geophys. Res., 108(D4), 8274, doi:10.1029/2001JD000579, 2003.

Ammann, M., Kalberer, M., Jost, D. T., Tobler, L., Rossler, E., Piguet, D., Gaggeler, H. W., and Baltensperger, U.: Hetergeneous production of nitrous acid on soot in polluted air masses, Nature, 395, 157-160, 1998.

Arens, F., Gutzwiller, L., Baltensperger, U., Gaggeler, H. W., and Ammann, M.: Heterogeneous reaction of NO2 on diesel soot particles, Environ. Sci. Technol., 35, 2191-2199, 2001.

Aumont, B., Chervier, F., and Laval, S.: Contribution of HONO sources to the $\mathrm{NO}_{\mathrm{x}} / \mathrm{HO}_{\mathrm{x}} / \mathrm{O}_{3}$ chemistry in the polluted boundary layer, Atmos. Environ., 37, 487-498, 2003.

Aumont, B., Madronich, S., Ammann, M., Kalberer, M., Baltensberger, U., Hauglustine, D., and Brocheton, F.: On the reaction of $\mathrm{NO}_{2}+$ soot in the atmosphere, J. Geophys. Res., 104, 17291736, 1999.

Bei, N., de Foy, B., Lei, W., Zavala, M., and Molina, L. T.: Using 3DVAR data assimilation system to improve ozone simulations in the Mexico City basin, Atmos. Chem. Phys., 8, 7353-7366, doi:10.5194/acp-8-7353-2008, 2008.

Bejan, I., Aal, Y. A. E., Barnes, I., Benter, T., Bohn, B., Wiesen, P., and Kleffmann, J.: The photolysis of ortho-nitrophenols: a new gas phase source of HONO, Phys. Chem. Chem. Phys., 8, 2028-2035, 2006.

Binkowski, F. S. and Roselle, S. J.: Models-3 Community Multiscale Air Quality (CMAQ) model aerosol component: 1. Model description, J. Geophys. Res., 4183, doi:10.1029/2001JD001409, 2003.

Brasseur, G. P., Orlando, J. J., and Tyndall, G. S.: Atmospheric chemistry and global change, Oxford University Press, New York, USA, 654 pp., 1999.

Calvert, J. G., Yarwood, G., and Dunker, A. M.: An evaluation of the mechanism of nitrous acid formation in the urban atmosphere, Res. Chem. Int., 20(3-5), 463-502, 1994.

Chen, F. and Dudia, J.: Coupling an advanced land-surface/hydrology model with the Penn State/NCARMM5modelingsystem. Part I: Model description and implementation, Mon. Weather Rev., 129, 569-585, 2001.

Clapp, L. J. and Jenkin, M.: Analysis of the relationship between ambient levels of $\mathrm{O}_{3}, \mathrm{NO}_{2}$ and $\mathrm{NO}$ as a function of $\mathrm{NO}_{\mathrm{x}}$ in the UK, Atmos. Environ., 35, 6391-6405, 2001.

de Foy, B., Fast, J. D., Paech, S. J., Phillips, D., Walters, J. T., Coulter, R. L., Martin, T. J., Pekour, M. S., Shaw, W. J., Kastendeuch, P. P., Marley, N. A., Retama, A., and Molina, L. T.: Basinscale wind transport during the MILAGRO field campaign and comparison to climatology using cluster analysis, Atmos. Chem. Phys., 8, 1209-1224, doi:10.5194/acp-8-1209-2008, 2008.

de Foy, B., Krotkov, N. A., Bei, N., Herndon, S. C., Huey, L. G.,
Martnez, A.-P., Ruiz-Surez, L. G., Wood, E. C., Zavala, M., and Molina, L. T.: Hit from both sides: tracking industrial and volcanic plumes in Mexico City with surface measurements and OMI SO2 retrievals during the MILAGRO field campaign, Atmos. Chem. Phys., 9, 9599-9617, doi:10.5194/acp-9-9599-2009, 2009.

Dudhia, J.: Numerical study of convection observed during the winter monsoon experiment using a mesoscale two-dimensional model, J. Atmos. Sci., 46, 3077-3107, 1989.

Dusanter, S., Vimal, D., Stevens, P. S., Volkamer, R., and Molina, L. T.: Measurements of $\mathrm{OH}$ and $\mathrm{HO}_{2}$ concentrations during the MCMA-2006 field campaign - Part 1: Deployment of the Indiana University laser-induced fluorescence instrument, Atmos. Chem. Phys., 9, 1665-1685, doi:10.5194/acp-9-1665-2009, 2009a.

Dusanter, S., Vimal, D., Stevens, P. S., Volkamer, R., Molina, L. T., Baker, A., Meinardi, S., Blake, D., Sheehy, P., Merten, A., Zhang, R., Zheng, J., Fortner, E. C., Junkermann, W., Dubey, M., Rahn, T., Eichinger, B., Lewandowski, P., Prueger, J., and Holder, $\mathrm{H}$.: Measurements of $\mathrm{OH}$ and $\mathrm{HO}_{2}$ concentrations during the MCMA-2006 field campaign: Part 2 - Model comparison and radical budget, Atmos. Chem. Phys., 9, 6655-6675, doi:10.5194/acp-9-6655-2009, 2009b.

Dzepina, K., Volkamer, R. M., Madronich, S., Tulet, P., Ulbrich, I. M., Zhang, Q., Cappa, C. D., Ziemann, P. J., and Jimenez, J. L.: Evaluation of recently-proposed secondary organic aerosol models for a case study in Mexico City, Atmos. Chem. Phys., 9, 5681-5709, doi:10.5194/acp-9-5681-2009, 2009.

Febo, A., De Santis, F., Perrino, C., and Liberti, A.: The study of the reaction between nitrogen oxides and water vapor by means of annular denuder tubes, in Tropospheric $\mathrm{NO}_{\mathrm{x}}$ Chemistry-Gas Phase and Multiphase Aspects, CEC Air Pollut. Res. Rep. 9, Nielsen \& Cox, Rosklide, Denmark, 61-67, 1987.

Febo, A., Perrino, C., and Allegrini, I.: Measurement of nitrous acid in Milan, Italy, by DOAS and diffusion denuders, Atmos. Environ., 30, 3599-3609, 1996.

Grell, G. A., Peckham, S. E., Schmitz, R., McKeen, S. A., Wilczak, J., and Eder, B.: Fully coupled "online" chemistry within the WRF model, Atmos. Environ., 39, 6957-6975, 2005.

George, C., Strekowski, R. S., Kleffmann, J., Stemmler, K., and Bencze, L.: Photoenhanced uptake of gaseous $\mathrm{NO}_{2}$ on solid organic compounds: A photochemical source of HONO?, Faraday Discuss, 130, 195-210, 2005.

Guenther, A., Karl, T., Harley, P., Wiedinmyer, C., Palmer, P. I., and Geron, C.: Estimates of global terrestrial isoprene emissions using MEGAN (Model of Emissions of Gases and Aerosols from Nature), Atmos. Chem. Phys., 6, 3181-3210, doi:10.5194/acp-63181-2006, 2006.

Guenther, A.: Corrigendum to "Estimates of global terrestrial isoprene emissions using MEGAN (Model of Emissions of Gases and Aerosols from Nature)" published in Atmos. Chem. Phys., 6, 3181-3210, 2006, Atmos. Chem. Phys., 7, 4327-4327, doi:10.5194/acp-7-4327-2007, 2007.

Gutzwiller, L., Arens, F., Baltensperger, U., Gaggeler, H. W., and Ammann, M.: Significance of semivolatile diesel exhaust organics for secondary HONO formation, Environ. Sci. Technol., 36, 677-682, 2002.

Harris, G. W., Carter, W. P. L., Winer, A. M., Pitts Jr., J. N., Platt, U., and Perner, D.: Observation of nitrous acid in the Los Angeles 
atmosphere and implications for predictions of ozone-precursor relationships, Environ. Sci. Technol., 16, 414-419, 1982.

Harrison, R. M., Peak, J. D., and Collins, G. M.: Tropospheric cycle of nitrous acid, J. Geophys. Res., 101, 14429-14439, 1996.

Hess, P. G., Flocke, S., Lamarque, J. F., Barth, M. C., and Madronich, S.: Episodic modeling of the chemical structure of the troposphere as revealed during the spring MLOPEX 2 intensive, J. Geophys. Res., 105, 26809-26839, 2000.

Hofzumahaus, A., Rohrer, F., Lu, K., Bohn, B., Brauers, T., Chang, C., Fuchs, H., Holland, F., Kita, K., Dondo, Y., Li, X., Lou, S., Shao, M., Zeng, L., Wahner, A., and Zhang, Y.: Amplified trace gas removal in the troposphere, Science, 324, 1702-1704, 2009.

Horowitz, L. W., Walter, S., Mauzerall, D. L., et al.: A global simulation of tropospheric ozone and related tracers: Description and evaluation of MOZART, version 2, J. Geophys. Res., 108(D24), 4784, doi:10.1029/2002JD002853, 2003.

Hodzic, A., Jimenez, J. L., Madronich, S., Aiken, A. C., Bessagnet, B., Curci, G., Fast, J., Lamarque, J.-F., Onasch, T. B., Roux, G., Schauer, J. J., Stone, E. A., and Ulbrich, I. M.: Modeling organic aerosols during MILAGRO: importance of biogenic secondary organic aerosols, Atmos. Chem. Phys., 9, 6949-6981, doi:10.5194/acp-9-6949-2009, 2009.

Jenkin, M. E., Cox, R. A., and Williams, D. J.: Laboratory studies of the kinetics of formation of nitrous acid from the thermal reaction of nitrogen dioxide and water vapor, Atmos. Environ., 22, 487498, 1988.

Kalberer, M., Ammann, M., Arens, F., Gäggeler, H. W., and Baltensperger, U.: Heterogeneous formation of nitrous acid (HONO) on soot aerosol particles, J. Geophys. Res., 104, 1382513832, 1999.

Kleffmann, J., Becker, K. H., and Wiesen, P.: heterogeneous NO2 conversion process on acid surfaces: possible atmospheric implications, Atmos. Environ., 32, 2721-2729, 1998.

Kleffmann, J., Becker, K. H., Lackhoff, M., and Wiesen, P.: Heterogeneous conversion of $\mathrm{NO}_{2}$ and $\mathrm{HONO}$ on carbonaceous surfaces, Phys. Chem. Phys., 1, 5443-5450, 1999.

Kleffmann, J., Lorzer, J. C., Wiesen, P., Kern, C., Trick, S., Volkamer, R., Rodenas, M., and Wirtz, K.: Intercomparison of the DOAS and LOPAP techniques for the detection of nitrous acid (HONO), Atmos. Environ., 40, 3640-3652, 2006.

Kleffmann, J.: Daytime sources of nitrous acid (HONO) in the atmospheric boundary layer, Chem. Phys. Chem., 8, 1137-1144, 2007.

Kotamarthi, V. R., Gaffney, J. S., Marley, N. A., and Doskey, P. $\mathrm{V}$.: Heterogeneous $\mathrm{NO}_{\mathrm{x}}$ chemistry in the polluted PBL, Atmos. Environ., 35, 4489-4498, 2001.

Kurtenbach, R., Becker, K. H., Gomes, J. A. G., Kleffmann, J., Lorzer, J. C., Spittler, M., Wiesen, P., Ackermann, R., Geyer, A., and Platt, U.: Investigations of emissions and heterogeneous formation of HONO in a road traffic tunnel, Atmos. Environ., 35, 3385-3394, 2001.

Lammel, G. and Cape, J. N.: Nitrous acid and nitrite in the atmosphere, Chem. Soc. Rev., 25, 361-369, 1996.

Lammel, G. and Perner, D.: The atmospheric aerosols as a source of nitrous acid in the polluted troposphere, J. Aerosol Sci., 19, 1199-1202.

Li, G., Zhang, R., Fan, J., and Tie, X.: Impacts of black carbon aerosol on photolysis and ozone, J. Geophys. Res., 110, D23206, doi:10.1029/2005JD005898, 2005.
Lei, W., Zhang, R., Tie, X., and Hess, P.:, Chemical characterization of ozone formation in the Houston-Galveston area, J. Geophys. Res., 109, D12301, doi:10.1029/2003JD004219, 2004.

Lin, Y.-L., Farley, R. D., and Orville, H. D., Bulk parameterization of the snow field in a cloud model, J, Appl, Meteorol,, 22, 10651092, 1983.

Merten, A.: New design of Long path-DOAS instruments based on fibre optics and applications in the study of the urban atmosphere, Thesis, Heidelberg Univ., Germany, 2008.

Mlawer, E. J., Taubman, S. J., Brown, P. D., Iacono, M. J., and Clough, S. A.: Radiative transfer for inhomogeneous atmosphere: RRTM, a validated correlated-k model for the long-wave, J. Geophys. Res., 102(D14), 16663-16682, 1997.

Molina, L. T., Madronich, S., Gaffney, J. S., and Singh, H. B.: Overview of MILAGRO/INTEX-B Campaign, IGAC Newsletter, Issue No. 38, pp. 2-15, 2008.

Molina, L. T., Madronich, S., Gaffney, J. S., Apel, E., de Foy, B., Fast, J., Ferrare, R., Herndon, S., Jimenez, J. L., Lamb, B., Osornio-Vargas, A. R., Russell, P., Schauer, J. J., Stevens, P. S., and Zavala, M.: An overview of the MILAGRO 2006 campaign: Mexico City emissions and their transport and transformation, Atmos. Chem. Phys. Discuss., 10, 7819-7983, doi:10.5194/acpd-10-7819-2010, 2010.

Monge, M. E., D’Anna, B., Mazri, L., Giroir-Fendler, A., Ammann, M., Donaldson, D. J., and George, C.: Light changes the atmospheric reactivity of soot, Proc. Natl. Acad. Sci., 107, 66056609, 2010.

Ndour, M., D’Anna, B., George, C., Ka, O., Balkanski, Y., Kleffmann, J., Stemmler, K., and Ammann, M.: Photoenhanced uptake of $\mathrm{NO}_{2}$ on mineral dust: Laboratory experiments and model simulations, Geophys. Res. Lett., 35(5), L05812, doi:10.1029/2007GL032006, 2008.

Ng, N. L., Kroll, J. H., Chan, A. W. H., Chhabra, P. S., Flagan, R. C., and Seinfeld, J. H.: Secondary organic aerosol formation from m-xylene, toluene, and benzene, Atmos. Chem. Phys., 7, 3909-3922, doi:10.5194/acp-7-3909-2007, 2007.

Noh, Y., Cheon, W. G., and Raasch, S.: The improvement of the Kprofile model for the PBL using LES. Preprints, Int. Workshop of Next Generation NWP Models, Seoul, South Korea, Laboratory for Atmospheric Modeling Research, 65-66, 2001.

Odum, J. R., Hoffman, T., Bowman, F., Collins, D., Flagan, R. C., and Seinfeld, J. H.:, Gas/particle partitioning and secondary organic aerosol yields, Environ. Sci. Technol., 30, 2580-2585, 1996.

Olaguer, E. P., Rappengluck, B., Lefer, B., Stutz, J., Dibb, J., Griffin, R., Brune, W. H., Shauck, M., Buhr, M., Jeffries, H., Vizuete, W., and Pinto, J. P.: Deciphering the Role of Radical Precursors during the Second Texas Air Quality Study, J. Air Waste Manage. Assoc., 59, 1258-1277, 2009.

Pankow, J. F.: An absorption model of gas/particle partitioning involved in the formation of secondary organic aerosol, Atmos. Environ., 28, 189-193, 1994.

Robinson, A. L., Donahue, N. M., Shrivastava, M. K., Weitkamp, E. A., Sage, A. M., Grieshop, A. P., Lane, T. E., Pandis, S. N., and Pierce, J. R.: Rethinking organic aerosols: semivolatile emissions and photochemical aging, Science, 315, 1259-1262, 2007.

Saliba, N. J., Mochiba M., and Finlayson-Pitts, B. J.: Laboratory studies of sources of HONO in polluted urban atmospheres, Geophys. Res. Lett., 27, 3229-3232, 2000. 
Schell, B., Ackermann, I. J., Hass, H., Binkowski, F. S., and Ebel A.: Modeling the formation of secondary organic aerosol within a comprehensive air quality modeling system, J. Geophys. Res., 106, 28275-28293, 2001.

Svensson, R., Ljungstrom, E., and Lindquist, O.: Kinetics of the reaction between nitrogen dioxide and water vapour, Atmos. Environ., 21, 1529-1539, 1987.

Skamarock, W. C., Klemp, J. B., Dudhia, J., Gill, D. O., Barker, D. M., Wang, W., and Powers, J. G.: A description of the Advanced Research WRF Version 2, NCAR Tech Notes-468+STR, National Center for Atmos. Res., Boulder, CO, USA, 100 pp., 2005.

Song, J., Lei, W., Bei, N., Zavala, M., de Foy, B., Volkamer, R., Cardenas, B., Zheng, J., Zhang, R., and Molina, L. T.: Ozone response to emission changes: a modeling study during the MCMA-2006/MILAGRO Campaign, Atmos. Chem. Phys., 10, 3827-3846, doi:10.5194/acp-10-3827-2010, 2010.

Staffelbach, T., Neftel, A., and Horowitz, L. W.: Photochemical oxidant formation over southern Switzerland. 2. Model results, J. Geophys. Res., 102, 23363-23373, 1997.

Sheehy, P. M., Volkamer, R., Molina, L. T., and Molina, M. J.: Oxidative capacity of the Mexico City atmosphere - Part 2: A $\mathrm{RO}_{\mathrm{x}}$ radical cycling perspective, Atmos. Chem. Phys. Discuss., 8, 5359-5412, 2008.

Stemmler, K., Ammann, M., Donders, C., Kleffmann, J., and George, C.: Photosensitized reduction of nitrogen dioxide on humic acid as a source of nitrous acid, Nature, 440, 195-198, 2006.

Stemmler, K., Ndour, M., Elshorbany, Y., Kleffmann, J., D’Anna, B., George, C., Bohn, B., and Ammann, M.: Light induced conversion of nitrogen dioxide into nitrous acid on submicron humic acid aerosol, Atmos. Chem. Phys., 7, 4237-4248, 2007.

Stutz, J., Kim, E. S., Platt, U., Bruno, P., Perrino, C., and Febo, A.: UV-invisible absorption cross section of nitrous acid, J. Geophys. Res., 105(D11), 14585-4592, 2000.

Tie, X., Madronich, S., Walters, S., Zhang, R., Rasch, P., and Collins, W.: Effect of clouds on photolysis and oxidants in the troposphere, J. Geophys. Res., 108(D20), 4642, doi:10.1029/2003JD003659, 2003.

Tie, X., Madronich, S., Li, G., Ying, Z., Zhang, R., Garcia, A. R., Taylor, L., and Liu, Y.: Characterizations of chemical oxidants in Mexico City: A regional chemical dynamical model (WRFChem) study, Atmos. Environ., 41, 1989-2008, 2007.

Vogel, B., Vogel, H., Kleffmann, J., and Kurtenbach, R.: Measured and simulated vertical profiles of nitrous acid-Part II. Model simulations and indications for a photolytic source, Atmos. Environ., 37, 2957-2966, 2003.
Volkamer, R., Jimenez, J. L., San Martini, F., Dzepina, K., Zhang, Q., Salcedo, D., Molina, L. T., Worsnop, D. R., and Molina, M. J.: Secondary organic aerosol formation from anthropogenic air pollution: Rapid and higher than expected, Geophys. Res. Lett., 33(17), L17811, doi:10.1029/2006GL026899, 2006.

Volkamer, R., Sheehy, P. M., Molina, L. T., and Molina, M. J.: Oxidative capacity of the Mexico City atmosphere - Part 1: A radical source perspective, Atmos. Chem. Phys. Discuss., 7, 53655412, doi:10.5194/acpd-7-5365-2007, 2007.

Wesely, M. L.: Parameterization of surface resistance to gaseous dry deposition in regional-scale numerical models, Atmos. Environ., 23, 1293-1304, 1989.

Willmott, C. J. and Wicks, D. E.: An empirical method for the spatial interpolation of monthly precipitation within California, Phys. Geogr., 1, 59-73, 1980.

Winer, A. M. and Biermann, H. W.: Long pathlength differential optical absorption spectroscopy (DOAS) measurements of gaseous $\mathrm{HONO}, \mathrm{NO}_{2}$ and $\mathrm{HCHO}$ in the California South Coast Air Basin, Res. Chem. Intermed., 20, 423-445, 1994.

Zavala, M., Herndon, S. C., Wood, E. C., Jayne, J. T., Nelson, D. D., Trimborn, A. M., Dunlea, E., Knighton, W. B., Mendoza, A., Allen, D. T., Kolb, C. E., Molina, M. J., and Molina, L. T.: Comparison of emissions from on-road sources using a mobile laboratory under various driving and operational sampling modes, Atmos. Chem. Phys., 9, 1-14, doi:10.5194/acp-9-1-2009, 2009.

Zhang, R., Leu, M.-T., and Keyser, L. F., Heterogeneous chemistry of HONO on liquid sulfuric acid: A new mechanism of chlorine activation on stratospheric sulfate aerosols, J. Phys. Chem., 100, 339-345, 1996.

Zheng, J., Zhang, R., Fortner, E. C., Volkamer, R. M., Molina, L., Aiken, A. C., Jimenez, J. L., Gaeggeler, K., Dommen, J., Dusanter, S., Stevens, P. S., and Tie, X., Measurements of $\mathrm{HNO}_{3}$ and $\mathrm{N}_{2} \mathrm{O}_{5}$ using ion drift-chemical ionization mass spectrometry during the MILAGRO/MCMA-2006 campaign, Atmos. Chem. Phys., 8, 6823-6838, doi:10.5194/acp-8-6823-2008, 2008.

Zhou, X., Beine, H. J., Honrath, R. E., Fuentes, J. D., Simpson, W., Shepson, P. B., and Bottenheim, J. W.: Snowpack photochemical production of HONO: A major source of $\mathrm{OH}$ in the arctic boundary layer in springtime, Geophys. Res. Lett., 28, 40874090, 2002. 